\title{
Environmental impacts of coastal fish farming: carbon and nitrogen budgets for trout farming in Kaldbaksfjørður (Faroe Islands)
}

\author{
Gunnvør á Norði ${ }^{1, *}$, Ronnie N. Glud ${ }^{2,3,4}$, Eilif Gaard ${ }^{1}$, Knud Simonsen $^{5}$ \\ ${ }^{1}$ Faroe Marine Research Institute, FO-110 Tórshavn, Faroe Islands \\ ${ }^{2}$ The Scottish Association for Marine Science, Scottish Marine Institute, Oban, Argyll, PA37 1QA, UK \\ ${ }^{3}$ Southern Danish University, Institute of Biology and Nordic Center for Earth Evolution (NordCEE), Odense M, Denmark \\ ${ }^{4}$ Greenland Climate Research Centre, 3900 Nuuk, Greenland \\ ${ }^{5}$ University of the Faroe Islands, Faculty of Science and Technology, FO-100 Tórshavn, Faroe Islands
}

\begin{abstract}
Flow of organic carbon $(\mathrm{OC})$ and nitrogen through a sea cage trout farm was calculated on the basis of detailed studies of the farming operation, water circulation, OC and nutrient transport and recycling processes in sediment. A third of the OC and nitrogen provided by fish food was incorporated into fish biomass, which is more than has been found in previous studies. Most OC input was respired by the fish (52 to $70 \%$ ), and $~ 63 \%$ of the associated nitrogen was lost as dissolved inorganic nitrogen (DIN), potentially stimulating pelagic primary production. Approx. $6 \%$ of carbon and $5 \%$ of nitrogen derived from fish food settled on the seabed, where it was either mineralized or accumulated in the sediment. Based on transect measurements of diagenetic activity, the farm footprint was found to cover an area 10 times the farm area. OC mineralization in the sediment increased linearly with increasing food input; the divergence between carbon efflux and oxygen uptake in sediment likewise increased with increasing food input, reflecting an increasing level of sediment reduction. Directly below the farm, the dissolved organic carbon (DOC) efflux was high (on average $53 \%$ of dissolved inorganic carbon efflux), indicating that DOC efflux is an important pathway for benthic carbon release below aquaculture farms. Overall, microbial processes removed 56 and $38 \%$ of OC and nitrogen, respectively, that settled to the seabed. During a $39 \mathrm{~d}$ break in farming activity, due to the combined effect of mineralization and resuspension of surface sediment, sediment conditions improved considerably.
\end{abstract}

KEY WORDS: Fish farming • Sediment · Organic enrichment • Nutrient enrichment • Organic matter mineralization $\cdot$ Carbon budget $\cdot$ Sedimentation $\cdot$ Benthic recovery

Resale or republication not permitted without written consent of the publisher

\section{INTRODUCTION}

Coastal cultivation of fish in floating net cages is a rapidly expanding industry worldwide, now providing a significant portion of the world's market in fish (FAO 2009). Fish are typically cultivated in cages or pens in sheltered coastal areas; they impact the marine environment primarily through release and accumulation of waste products (Pillay 2004). Since these areas often have little water exchange, carrying capacity is limited, and the environment may be heavily affected. The oxygen consumption of the farmed fish and asso- ciated microbes in the cages may put excessive demand on the dissolved oxygen (DO) supply, reducing it severely (Johansson et al. 2007). Likewise, ammonia excretion from the farmed fish can lead to elevated ammonium concentrations in the cages (Brooks \& Mahnken 2003, Islam 2005), which may have negative effects on fish health.

Since nitrogen is the limiting nutrient in many marine environments, the input of ammonium might lead to increased primary production and changes in the plankton community. Such effects are usually not observed at the fish farm itself (Brooks \& Mahnken 
2003, Islam 2005, Pitta et al. 2006), but increased nutrient loading from fish farming may cause such effects on a regional scale (Karakassis et al. 2005). Pelagic effects are highly dependent on hydrographic and nutrient status in the farming area.

Models have shown little effect on primary production in a Norwegian fjord (Skogen et al. 2009). However in oligotrophic waters in southern Tasmania, theoretical models indicate significant impact on primary production, especially during summer and autumn when surface waters are otherwise nutrientdepleted (Wild-Allen et al. 2010).

Particulate waste products in the form of fish food and faeces quickly sink to the seafloor (Cromey et al. 2002). The sedimentation of organic carbon (OC) below fish farms has been found to be from 4 to 27 times higher than at unaffected sites, declining rapidly with distance from the farm (Hall et al. 1990, Chamberlain \& Stucchi 2007, Holmer et al. 2007, Kutti et al. 2007). The high deposition of waste particles in the sediment near aquaculture operations stimulates metabolic activity in the sediment and hence the consumption of electron acceptors, resulting in changed pathways for carbon mineralization and nutrient regeneration (Christensen et al. 2003, Valdemarsen et al. 2009).

Dissolved inorganic carbon (DIC) efflux and total oxygen uptake (TOU) in sediments below fish farms often is an order of magnitude higher than at non-fishfarm sites (Hall et al. 1990, Findlay \& Watling 1997, Holmer et al. 2002, 2003, Nickell et al. 2003, Giles 2008). Elevated ammonium effluxes and nitrogen uptake are likewise common in sediments impacted by fish farms (Hall et al. 1992, Holmer \& Kristensen 1992, Christensen et al. 2000, Holmer et al. 2002, Nickell et al. 2003).

Reduced sulphur species accumulate in the sediment, where they can be released to the overlying water, causing local elimination of fauna and hampering the well-being of the farmed fish (Black et al. 1996, Hargrave et al. 2008). In some cases, enhanced methanogenesis may even lead to release of methane gas (Hall et al. 1990, Holmer et al. 2002).

In order to halt serious deterioration of sediment conditions below fish farms, it is necessary to move the cages from time to time, allowing the sediment to recover. However, in many regions of the world, suitable fish farm areas are limited by space constraints and legislation. Many farming operations, laboring under such constraints, must intensify production for economic profitability, putting an even greater strain on the local environment (FAO 2009).

From the perspective of environmentally sustainable estuarine environments, it is essential to evaluate the wider impact of farming wastes on the plankton com- munity and how this interrelates with carrying capacity. The subject of environmental impact of aquaculture has received a lot of attention worldwide, and an emerging view is that aquaculture operations should be managed using an ecosystem-based approach (Soto et al. 2008). However, the nature of farm impacts are very dependent on local characteristics such as hydrodynamic conditions, temperature and water depth at the site (Kempf et al. 2002), as well as on farm size and husbandry methods (Mente et al. 2006).

In trying to manage a fish farm in an environmental context, a thorough knowledge of the associated waste load is essential-not only the quantity, but also the quality: Is it particulate or dissolved, organic or inorganic (Strain \& Hargrave 2005)? Quantification may be approached by carbon and nitrogen mass balances (e.g. Hall et al. 1990, Holmer et al. 2002, Strain \& Hargrave 2005). In most studies, however, mass balance calculations are based on information gathered from several studies, and under different environmental and physiological conditions, which in some cases may affect the estimated budgets.

Aquaculture has been rapidly growing in the Faroe Islands; in 2009 the country was ranked the world's fifth-largest producer of Atlantic salmon Salmo salar, exporting $47800 \mathrm{t}$ of farmed salmonid fish that year. Fish farming is licensed in the vast majority of fjords and sounds in the Faroe Islands, and is the major source of anthropogenic $\mathrm{OC}$ and nutrients in these coastal areas (Mortensen 1990). For sustainable management of the impacted ecosystems, it is imperative to understand how they function and how they respond to increased loading of nutrients and organic matter.

In the present study we investigated the dispersal of $\mathrm{OC}$ and nutrient wastes from a fish farm and their impact not only on the water column at the farm, but also on the seabed in the farm vicinity. We estimated how much of the OC and nitrogen added to the system in feed was incorporated into the farmed fish, how much was lost to the environment in particulate and dissolved form, and the effect of this loss on the benthic diagenetic pathway. Results of these studies were combined into an overall mass balance for carbon and nitrogen flow in the farm area. We furthermore investigated the relative importance of mineralization and resuspension on the short-term local sediment recovery rates following intense farming activity. The present study contributes to the knowledge base of environmental impact of farming activity on high-latitude fjord systems.

\section{MATERIALS AND METHODS}

Study site. The study was conducted in Kaldbaksfjørður, Faroe Islands, a fjord $6.6 \mathrm{~km}$ long and from 500 
to $1700 \mathrm{~m}$ wide, with a surface area of $5.41 \mathrm{~km}^{2}$. At the entrance is a sill from 30 to $40 \mathrm{~m}$ deep; maximum fjord depth is $60 \mathrm{~m}$ (Fig. 1). Most of the year the water column is 2-layered, with a fresher and warmer surface layer (salinity from 32.1 to 34.9 and temperature from 5.8 to $11.4^{\circ} \mathrm{C}$ ) receiving freshwater run-off from the $42 \mathrm{~km}^{2}$ catchment area, and a deeper water mass in contact with seawater from the sound outside the fjord (salinity from 34.9 to 35.3 and temperature from 6.2 to $10.8^{\circ} \mathrm{C}$ ). The pycnocline is generally situated between 8 and $20 \mathrm{~m}$ depth. During summer, however, an additional thermocline periodically appears at $\sim 40 \mathrm{~m}$ depth.

The hydrography is highly influenced by wind. Stormy periods with daily mean wind speeds of 15 to $20 \mathrm{~m} \mathrm{~s}^{-1}$ frequently induce water-column mixing. This may happen in all seasons, although it is more common during winter (Hansen 1990). Most of the catchment area is uncultivated and uninhabited, hence the anthropogenic input of labile OC and nutrients is minor. However, fish farming has been operating periodically in the fjord since 1985, and this is the major source of anthropogenic OC and nitrogen to the system (Mortensen 1990). In 2006, 2 areas - each approx. $0.25 \mathrm{~km}^{2}$ in extent-were licensed for fish farming. One was near the fjord mouth, and one relatively far from it. We studied the latter site (Fig. 1).

The study was conducted at farming site FS (Fig. 1), which had been without farming activity for more than 6 mo prior to late April 2006, when juvenile rainbow trout Oncorhynchus mykiss were introduced into cages there (Fig. 1). Farming continued uninterrupted until 2 October 2006, at which time the platform from which the cages were suspended was temporarily moved to an outer location in the fjord. Moorings, however, were not removed, and on 9 November 2006 the same plat-

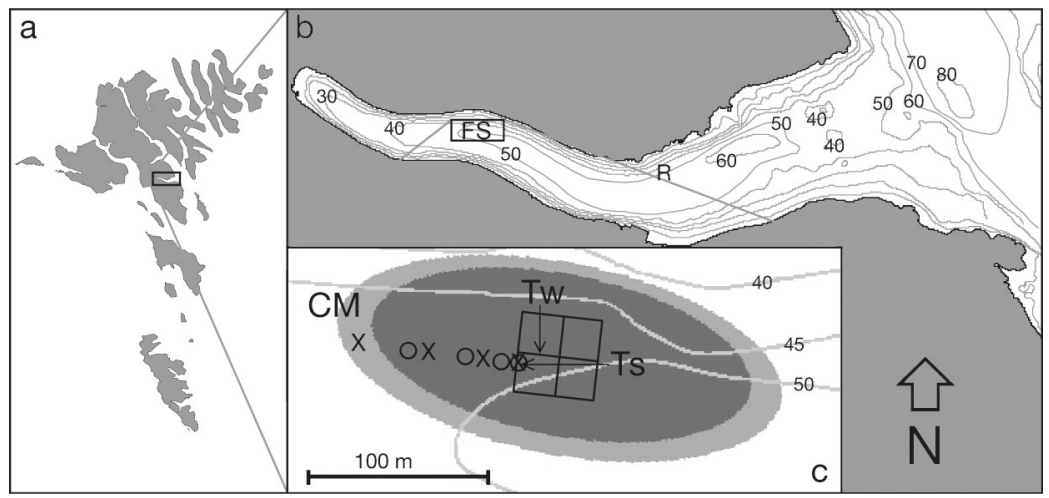

Fig. 1. (a) The Faroe Islands, (b) Kaldbaksfjørður—showing locations of farm site (FS) and reference station (R) - and (c) farm site. Ts indicates location of sediment time-series measurements; Tw indicates location of time-series water and sedimentation samples; CM indicates location of current measurements. Stations sampled on 22 June (O) and on 7 September (X). Light grey in (c) indicates maximum extent of estimated footprint area and dark grey minimum extent of that area form (with the same fish) was reinstalled to the same moorings, and farming continued until 3 April 2007.

Our sampling period was April 2006 to May 2007.

The location contained 10 net cages: 4 cages of $20 \times$ $20 \mathrm{~m}$ each, mounted below a floating platform covering an area of $2025 \mathrm{~m}^{2}$, and 6 circular cages (diameter $25 \mathrm{~m}$ ) located $125 \mathrm{~m}$ away. We studied only the square cages, and farming activity at the circular cages did not affect conditions at the stations sampled from the platform. Sediment time-series samples were collected at regular intervals during the 13 mo study period on the west side of the platform $1.5 \mathrm{~m}$ away from the platform-mounted net cages (water depth 48 m; Fig. 1c). Additionally, on 22 June 2006, sediment samples were taken along a transect at 0, 10, 30 and $60 \mathrm{~m}$ distance from the farm ( $t_{1}$; Fig. 1c) and on 7 September 2006 at $0,20,50$ and $90 \mathrm{~m}$ distance ( $\mathrm{t}_{2} ;$ Fig. $\left.1 \mathrm{c}\right)$. A reference station (R) at $52 \mathrm{~m}$ depth and $2.2 \mathrm{~km}$ ESE of the fish farming site (Fig. 1) was sampled in parallel on all sampling dates. Sediment characteristics are given in Table 1.

During the sampling period the total production of farmed fish in the fjord was $2440 \mathrm{t}$ (wet wt), and the total feed supply was $2932 \mathrm{t}$ (dry wt).

Measurements in water column. Vertical salinity and temperature profiles were obtained with a precalibrated Seabird SBE 37-SM MicroCAT. Currentdepth profiles were measured at the fish farm using a bottom-mounted Acoustic Doppler Current Profiler (AADI $600 \mathrm{kHz}$ RDCP600) deployed at $47 \mathrm{~m}$ depth during the period 23 March to 25 April 2006. Recordings were made at 20 min intervals; they represent the mean current over $2 \mathrm{~m}$ thick bins with the center of the deepest bin at $44 \mathrm{~m}$ depth.

Seawater for determination of $\mathrm{NO}_{3}{ }^{-}, \mathrm{NH}_{4}{ }^{+}, \mathrm{DO}, \mathrm{chl} a_{\text {, }}$ primary production, DIC and particulate organic carbon (POC) was sampled at 1, 5, 10, 20 and $45 \mathrm{~m}$ depth with a 51 Niskin sampler. For DO and DIC concentration measurements, the water was transferred to gas-tight glass vials. DO concentration was determined by Winkler titration (Grasshoff et al. 1999), while DIC samples were preserved with $20 \mu \mathrm{l}$ of $\mathrm{HgCl}_{2}(5 \% \mathrm{w} / \mathrm{v})$ until later analysis on an infrared gas analyzer (ADC-225-MK3). $\mathrm{NO}_{3}^{-}$and $\mathrm{NH}_{4}{ }^{+}$ samples were preserved with 3 droplets of chloroform per $20 \mathrm{ml}$ sample. $\mathrm{NO}_{3}{ }^{-}$ was measured on an auto analyzer according to Grasshoff et al. (1999) and ammonium was measured manually by the salicylate-hyperchlorite method, with a 35 saline standard curve (Bower \& Holm-Hansen 1980). The detection limit was 0.2 and $0.5 \mu \mathrm{M}$ for ammonium and nitrate, respectively, and the accu- 
Table 1. Sediment characteristics $( \pm \mathrm{SE})$ at farming site prior to and during farming, 22 June to 29 September, and 5 December 2006. Reference station not statistically different from farming site prior to farming (2-tailed t-test, $\mathrm{p}<0.05)$. Numbers in parentheses are total number of samples. Bold = significant difference between farming site conditions prior to and during farming; nd $=$ not determined

\begin{tabular}{|c|c|c|c|}
\hline & Farming site prior to farming & Farming site during farming & Reference station \\
\hline \multicolumn{4}{|l|}{ Grain size $(\% \text { of total })^{\mathrm{a}}$} \\
\hline$<63 \mu \mathrm{m}$ & $51 \pm 1.6(2)$ & $52 \pm 2.4(4)$ & $45 \pm 1.7(2)$ \\
\hline $63-250 \mu \mathrm{m}$ & $46 \pm 1.0(2)$ & $36 \pm 1.9(4)$ & $48 \pm 3.9(2)$ \\
\hline$>250 \mu \mathrm{m}$ & $2 \pm 0.3(2)$ & $10 \pm 1.0$ & $6 \pm 5.0(2)$ \\
\hline Density $\left(\mathrm{g} \mathrm{cm}^{-3}\right)^{\mathrm{a}}$ & $1.29 \pm 0.003(3)$ & $1.07 \pm 0.027(20)$ & $1.29 \pm 0.02(27)$ \\
\hline Porosity $^{\mathrm{a}}$ & $0.72 \pm 0.004(3)$ & $0.75 \pm 0.016(20)$ & $0.71 \pm 0.01(27)$ \\
\hline Organic carbon $\left(\mathrm{mmol} \mathrm{g}{ }^{-1}\right.$ dry wt) ${ }^{a}$ & $1.88 \pm 0.02(5)$ & $\mathbf{5 . 5 5} \pm \mathbf{0 . 3 7}(24)$ & $1.78 \pm 0.07(31)$ \\
\hline Nitrogen $\left(\mathrm{mmol} \mathrm{g}^{-1}\right.$ dry wt) ${ }^{\mathrm{a}}$ & $0.2 \pm 0.01(5)$ & $0.41 \pm 0.02(24)$ & $0.2 \pm 0.01$ \\
\hline Macrofauna abundance (ind. $\mathrm{m}^{-2}$ ) & nd & $2192 \pm 875(10)$ & $6411 \pm 641(20)$ \\
\hline \multicolumn{4}{|l|}{ Most abundant species (\% of total) ${ }^{\mathrm{b}}$} \\
\hline Abra nitida & nd & $0(5)$ & $48.0 \pm 5.7(20)$ \\
\hline Thyasira flexuosa & nd & $0(5)$ & $30.2 \pm 3.4(20)$ \\
\hline Scalibregma inflatum & nd & $9.2 \pm 12.3(5)$ & $14.7 \pm 5.3(20)$ \\
\hline Capitella capitata & nd & $59.4 \pm 6.0(5)$ & $0(20)$ \\
\hline
\end{tabular}

racy was better than $0.2 \mu \mathrm{M}$. Chl a was measured spectrophotometrically according to Parsons et al. (1984), after filtration of 21 seawater, and was calculated according to Jeffrey \& Humphrey (1975), with a detection limit and precision of 0.2 and $>0.05 \mu \mathrm{g} \mathrm{l^{-1 }}$ respectively. For POC determination, 11 of seawater was filtered through pre-combusted $\left(475^{\circ} \mathrm{C}\right)$ Whatman GF/F filters, and analyzed on a CE 440 Elemental analyzer (precision $>99 \%$ ) after being fumed with concentrated $\mathrm{HCl}$.

Primary production was measured in samples recovered from 5 and $20 \mathrm{~m}$ water depth using the $\mathrm{H}^{14} \mathrm{CO}_{3}{ }^{-}$ incubation approach (Steemann-Nielsen 1952) in an incubator exposed to a light gradient (see paragraph below). The 2 sampling depths generally represent phytoplankton communities with potentially different light adaptation from well mixed water bodies above and below the pycnocline. Samples were transferred to $40 \mathrm{ml}$ plastic bottles and stored dark and cold $\left(\sim 5^{\circ} \mathrm{C}\right)$ until arrival at the laboratory ( 2 to $3 \mathrm{~h}$ later). After addition of $1.2 \mu \mathrm{Ci}$ of $\mathrm{H}^{14} \mathrm{CO}_{3}{ }^{-}$, the bottles were placed on a rotating wheel and incubated at in situ temperature $\pm 1^{\circ} \mathrm{C}$ for $2 \mathrm{~h}$. Philips TLD 15W/33 lamps were used as the light source, providing each bottle with 1 of 11 light intensities from 210 to $16 \mu \mathrm{E} \mathrm{m}^{-2} \mathrm{~s}^{-1}$. After incubation, the content of each bottle was filtered on Whatman GF/F filters, and the radioactivity was measured on a Packard Tri-Carb 1500 liquid scintillation counter after addition of scintillation liquid. For each of the 2 depths, a production versus irradiance (PI) curve was constructed based on 12 light bottles and corrected for dark-fixation (2 dark bottles).

The light intensity range during incubation was within the in situ light intensity range, which varies with season, and no photoinhibition was observed. The chl a-normalized primary production at depth $z$ was calculated according to Sakshaug et al. (1992):

$$
P_{z}^{B}=P_{\max }^{B} \times\left(1-e^{\left(\frac{-\alpha^{B} \times I_{z}}{P_{\max }}\right)}\right)
$$

where $P_{\max }^{B}$ is the chl a-normalized light-saturated primary production, $\alpha^{B}$ is the photosynthetic efficiency and $I_{z}$ is the irradiance at depth $z$. Daily primary production was calculated from the PI curve, taking into account the in situ irradiance and the chl a content at 1 , $5,10,20$, and $50 \mathrm{~m}$ depth, with linear extrapolation between the measuring points.

Sedimentation. Duplicate sedimentation traps (KCDenmark; Lundsgaard et al. 1999) were moored to the platform at 20,40 and $45 \mathrm{~m}$ depths, and also at the reference station at 20, 40 and $50 \mathrm{~m}$ depths. On 7 September 2006, additional traps were moored 20, 50 and $90 \mathrm{~m}$ away from the platform, at 20 and $40 \mathrm{~m}$ depth. The flux in the traps at $20 \mathrm{~m}$ depth was assumed representative of vertical settling of material from the euphotic zone, while the general elevation in flux in the deeper traps was ascribed to resuspension.

The traps were replaced approximately every second week. One trap from each station + depth combination was kept unpreserved while the other was preserved with formaldehyde added to dense seawater (salinity $\sim 60$ ). After recovery of traps, subsamples of the content were filtered on pre-combusted $\left(475^{\circ} \mathrm{C}\right)$ and pre-weighed Whatman GF/F filters. The filters were flushed with artificial saline water in order to remove dissolved $\mathrm{OC}$ and nitrogen. The flux of total particulate material was determined by the weight 
gain of the filter after filtration and drying at $60^{\circ} \mathrm{C}$. POC and particulate nitrogen content was determined (as \% dry wt) from sub-samples of the dried filters, after fuming with $\mathrm{HCl}$.

In the present study we used results only from the preserved traps, although they might have been compromised by migrating zooplankton caught in the traps. The unpreserved traps might, for their part, have been affected by zooplankton grazing and microbial degradation (Gundersen \& Wassmann 1990). At $20 \mathrm{~m}$ depth at the fish farm, the carbon content in the preserved traps was $1.4 \pm 0.2$ times as high as in the unpreserved traps at the same depth. The preserved:unpreserved carbon content ratio at the reference station was $1.7 \pm 0.3$. At the fish farm the $\mathrm{C}: \mathrm{N}$ ratio of the sinking particles in the preserved and unpreserved traps was $11.2 \pm 1.1$ and $12.2 \pm 1.3$, respectively, and at the reference station it was $7.1 \pm 0.3$ and $7.8 \pm 0.3$, respectively. For assessment of pelagic-benthic coupling, the trap data were complemented with detailed benthic mapping of $\mathrm{OC}$ accumulation and mineralization rates within the footprint (see 'Sediment characteristics').

Sediment characteristics. Sediment was retrieved with a HAPS bottom corer (KC-Denmark; Kanneworf \& Nicolaisen 1973). Only cores with a clear water phase were used. For further analysis sub-cores were collected in Plexiglas tubes (internal diameter $=5.6 \mathrm{~cm}$ ). Cores were kept dark and at bottom-water temperature during transport to the laboratory, which was reached within $4 \mathrm{~h}$ of sampling. For determination of porosity, total organic carbon (TOC) and total nitrogen (TN) content, 2 cores from each station were sectioned into $1 \mathrm{~cm}$ intervals down to $4 \mathrm{~cm}$ depth, and $2 \mathrm{~cm}$ intervals from 4 to $12 \mathrm{~cm}$ depth. Sediment porosity was determined from density and water content measured as the weight loss after drying at $70^{\circ} \mathrm{C}$ for $\sim 48 \mathrm{~h}$. TOC and TN were measured on a CE 440 Elemental analyzer after the sediment had been homogenized, acidified (with 4 to $\left.5 \% \mathrm{H}_{2} \mathrm{SO}_{4}\right)$, and dried. For macrofauna identification, sediment cores were sieved (1 mm mesh size) and preserved with formalin until later counting and identification down to lowest possible taxonomic level.

Sediment water fluxes. Upon return to the laboratory 3 sediment cores from each station were submerged in an incubation tank, holding bottom water at in situ temperature $\pm 0.5^{\circ} \mathrm{C}$. On most sampling dates, the in situ bottom-water DO concentrations corresponded to $90 \%$ to $100 \%$ air saturated; water in the incubation tank was flushed with air, maintaining the ambient water at $100 \%$ air saturation. However, on 2 sampling dates, 22 August and 7 September 2006, the in situ DO concentration of the bottom water was only $~ 50 \%$ of air saturation. On 22 August, the incubation water was flushed with a mixture of nitrogen and air, keeping the oxygen concentration at $60 \%$ air saturation, but on
7 September (the date of the second transect measurements), the incubation water was mistakenly flushed with air only (no added nitrogen) and these data must therefore be treated with caution. In order to ensure well mixed conditions in the core liners, small Tefloncoated magnets were attached to the inner wall of the cores, their momentum imparted by an externally rotating magnet (Rasmussen \& Jørgensen 1992). The stirring resulted in a measured effective diffusive boundary layer (DBL) thickness of $364 \pm 13 \mu \mathrm{m}$ (data not shown).

After pre-incubation of 12 to $24 \mathrm{~h}$ the cores were closed, leaving an internal water height of approximately $8 \mathrm{~cm}$. Oxygen concentration in the cores was monitored with a Clark-type oxygen minielectrode with a tip diameter of $500 \mu \mathrm{m}, 90 \%$ response time of $\sim 15 \mathrm{~s}$ and stirring sensitivity of $<2 \%$ (Revsbech 1989, Glud et al. 1995a). Seawater samples for measurements of DO, DIC, DOC, $\mathrm{NO}_{3}{ }^{-}$and $\mathrm{NH}_{4}{ }^{+}$were taken at the start of the incubation and when the oxygen concentration inside the respective cores had decreased 15 to $20 \%$. Samples were collected with a gas-tight syringe equipped with a Tygon tube. Samples for $\mathrm{NO}_{3}{ }^{-}, \mathrm{NH}_{4}{ }^{+}, \mathrm{DO}$ and DIC were stored and analyzed in the same way as the water column measurements. Samples for DOC measurements were filtered through pre-combusted $\left(475^{\circ} \mathrm{C}\right)$ Whatman $\mathrm{GF} / \mathrm{F}$ filters, and acidified with $1.2 \mathrm{M} \mathrm{HCl}$ for later analysis on a TOC analyzer (T5000 Shimadzu). Sediment water fluxes were calculated linearly from the change in solute concentration during incubation, accounting for incubation time and enclosed water volume. A linear decline in the DO concentration was confirmed from the continuous recording of the minielectrode. Sediment uptake is defined as a negative flux while sediment release is defined as a positive flux.

Oxygen microprofiles. Oxygen profiles were measured in the same cores $12 \mathrm{~h}$ after the flux measurements had been terminated by cap removal. Profiles were obtained with a Clark-type microelectrode equipped with a guard cathode and an internal reference (Revsbech 1989). The tip diameter was $\sim 10 \mu \mathrm{m}$, stirring sensitivity $<1 \%$ and the $90 \%$ response time was $<1$ s (Gundersen et al. 1998, Glud et al. 2000). Three profiles were measured in each core, adding up to a total of 9 microprofiles at each measuring event. The microelectrodes were positioned by a motordriven micromanipulator and profiles were measured at a depth resolution of 50 or $100 \mu \mathrm{m}$. The sensor current was measured by a picoammeter connected to an analogue-digital converter, which transferred the signal to a PC (Revsbech \& Jørgensen 1986). The microelectrode was calibrated by 2-point calibration from the signal in the well mixed air-saturated water and the signal of the anoxic sediment. 
The oxygen penetration depth obtained from the oxygen microprofiles was defined as the depth between the sediment surface and the onset of the constant anoxic signal. The position of the sediment surface was estimated from a shift in the linear concentration gradient in the DBL of the individual profiles (Glud et al. 1995b). The diffusive oxygen uptake (DOU) was calculated from the calibrated microprofiles by DOU $=-\mathrm{D}_{0} \delta \mathrm{C} / \delta z_{\text {, where }} \mathrm{D}_{0}$ is the temperature-corrected molecular diffusion coefficient and $\mathrm{C}$ the oxygen concentration at depth $z$ within the DBL (Jørgensen \& Revsbech 1985). Higher total oxygen uptake (TOU) than DOU is generally ascribed to fauna-mediated oxygen uptake in the form of respiration and irrigation (Archer \& Devol 1992, Glud 2008).

Farming activity. Information on fish biomass and food usage was acquired from the farmer. The farming operation was controlled by a farm control monitoring system with automatic feeding (http://www.akvagroup. com).

Total carbon, nitrogen and water content in relation to fish size were determined on 14 rainbow trout Oncorhynchus mykiss (weight from 200 to $1700 \mathrm{~g}$ each) from the same tribe, fed the same food as the fish farmed in Kaldbaksfjørður. Individual weight and fork length were measured and the gut content removed, prior to mincing in a Bear Varimixer Type AR 10 (A/S Wodschow \& Co, Denmark). Three subsamples from each fish were dried at $70^{\circ} \mathrm{C}$ until reaching constant weight. The water content was determined as the weight loss, and total carbon and nitrogen content was measured after the dried samples had been ground up and homogenized by hand. Dry wt, organic carbon and nitrogen content were also measured on both food pellets and faeces from juvenile ( $90 \mathrm{~g})$ and adult fish (1.5 to $2.5 \mathrm{~kg}$ ). Faecal pellets were collected from sedimentation traps deployed at the farming site for $24 \mathrm{~h}$, and dry wt, TOC and nitrogen content was determined on 6 individual pellets. Food samples used for the 2 fish sizes were obtained from the farmer.

\section{RESULTS}

\section{Farming activity and sedimentation}

Farming activity at this site started in late April, when $~ 770000$ juvenile rainbow trout Oncorhynchus mykiss (100 to $105 \mathrm{~g}$ each) were released into cages at the farming site. Approximately $35 \%$ of the fish were placed in the 4 square cages attached to the platform (Fig. 1c). The amount of feed usage at the platform gradually increased from this point into early July, after which the feed supply was held relatively constant at $\sim 470 \mathrm{gC} \mathrm{m}^{-2} \mathrm{~d}^{-1}$ (Fig. 2a). From 2 October to 9 November there was no farming activity at the site.

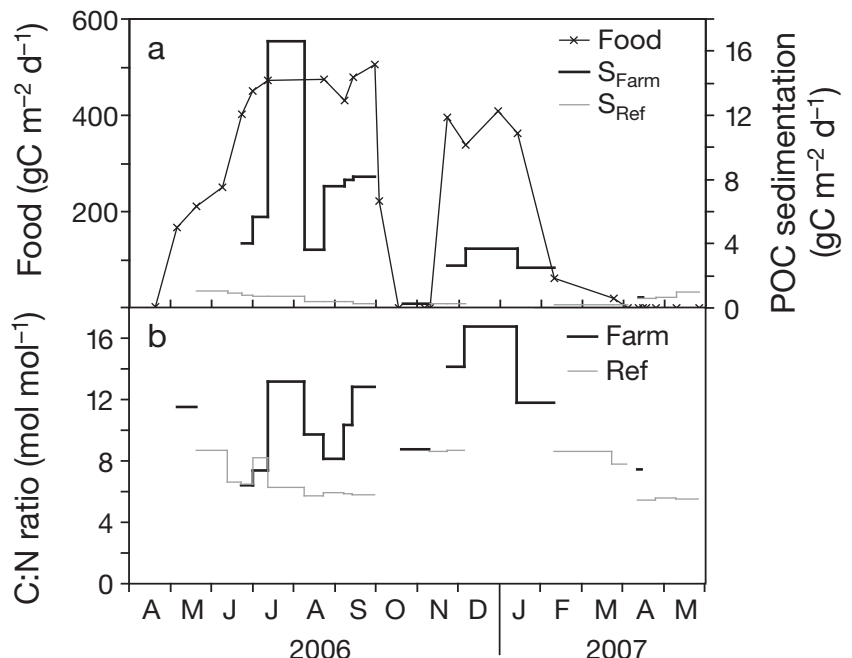

Fig. 2. (a) Daily carbon supply from food and particulate organic carbon (POC) sedimentation at fish farm $\left(\mathrm{S}_{\mathrm{Farm}}\right)$, also showing POC data for reference station $\left(\mathrm{S}_{\mathrm{Ref}}\right)$; and (b) C:N ratio of sedimenting material for both sites. All measurements made at $20 \mathrm{~m}$ depth in water column. Width of intervals given

for sedimentation represents deployment time of traps

After the platform and cages containing fish were reinstalled, farming continued, with a feeding rate of $\sim 380 \mathrm{gC} \mathrm{m}^{-2} \mathrm{~d}^{-1}$ until February 2007, when the majority of the fish stock was permanently removed. Approx. 61500 specimens of $0.9 \mathrm{~kg}$ trout were left in the cages until April 2007, at a feeding rate of $\sim 40 \mathrm{gC}$ $\mathrm{m}^{-2} \mathrm{~d}^{-1}$. They were removed on 3 April 2007.

POC sedimentation was highly variable. During the period of relatively constant feeding rate, $\sim 470 \mathrm{gC} \mathrm{m}^{-2}$ $\mathrm{d}^{-1}$, POC sedimentation varied between 3.6 and $16.6 \mathrm{gC} \mathrm{m}^{-2} \mathrm{~d}^{-1}$, while in the later farming period with a feeding rate of $\sim 380 \mathrm{gC} \mathrm{m}^{-2} \mathrm{~d}^{-1}$, POC sedimentation was only between 2.5 and $3.7 \mathrm{gC} \mathrm{m}^{-2} \mathrm{~d}^{-1}$ (Fig. 2a). Thus no apparent relation existed between feeding rate and POC sedimentation directly below the farm (Fig. 2a). This was possibly due to temporally variable local hydrodynamics affecting the distribution of the sinking material, or possibly to a variable feeding rate. Sedimentation at the farm was nevertheless much higher than at the reference station. From July to September average sedimentation at the farming site was $9.7 \pm$ $2.6 \mathrm{gC} \mathrm{m}^{-2} \mathrm{~d}^{-1}$ while at the reference station during the same period it only was $0.50 \pm 0.09 \mathrm{gC} \mathrm{m}^{-2} \mathrm{~d}^{-1}$. Sedimentation was, moreover, markedly reduced at the farming site after the fish farm was removed (Fig. 2a).

During farming activity the $\mathrm{C}: \mathrm{N}$ ratio of the settling material was clearly higher at the farm $(12.2 \pm 0.9)$ than at the reference station $(7.1 \pm 0.3$; Fig. $2 b)$. For comparison, the $\mathrm{C}: \mathrm{N}$ ratio of fish feed used for juveniles was $7.6 \pm 0.2$, and for adults $(>1.3 \mathrm{~kg}), 10.2 \pm 0.3$. The $\mathrm{C}: \mathrm{N}$ ratio of faecal pellets of juveniles and adult trout was $13.2 \pm 1.6$ and $18.1 \pm 0.6$, respectively. This indicates 
that the majority of particulate wastes settling below and around the farm was faecal rather than feed pellets. Only occasionally was the C:N ratio relatively low, indicating trapped fish feed (Fig. 2b).

Since hydrography, primary production, chl a content and algal composition were highly similar between the farm and the reference station, it is reasonable to assume that natural sedimentation at the farm and reference station were similar as well. On the basis of this assumption, from 22 June to 29 September 2006 (the period of continuous sedimentation measurements at the farm site; Fig. 2a), of the total POC sedimentation of $914 \mathrm{gC} \mathrm{m}^{-2}, 5.6 \%$ was natural material. Using this same assumption, of total sedimentation of nitrogen during this period $\left(101 \mathrm{gN} \mathrm{m}^{-2}\right), 9.4 \%$ was of natural origin.

\section{Rainbow trout carbon and nitrogen content}

The water content of farmed rainbow trout was $70.5 \pm 0.6 \%$, a percentage that did not change with fish weight. However the weight \% of $\mathrm{C}$ content showed a logarithmic increase with increasing fish weight, while the weight \% of $\mathrm{N}$ showed a logarithmic decrease with increasing fish weight (Fig. 3). Overall the C:N ratio gradually increased from 5.0 for juveniles to 8.7 for adult fish $(\sim 1.5 \mathrm{~kg})$.

\section{Effects of fish farming on water column}

Current velocity and direction was relatively uniform throughout the water column. From 23 March to 25 April 2006 current velocity ranged between 0.2 and $18.2 \mathrm{~cm} \mathrm{~s}^{-1}$ at $6 \mathrm{~m}$ depth, with a mean $( \pm \mathrm{SD})$ of $5.7 \pm$ $5.7 \mathrm{~cm} \mathrm{~s}^{-1}$, while at $3 \mathrm{~m}$ above the seabed (44 $\mathrm{m}$ depth)

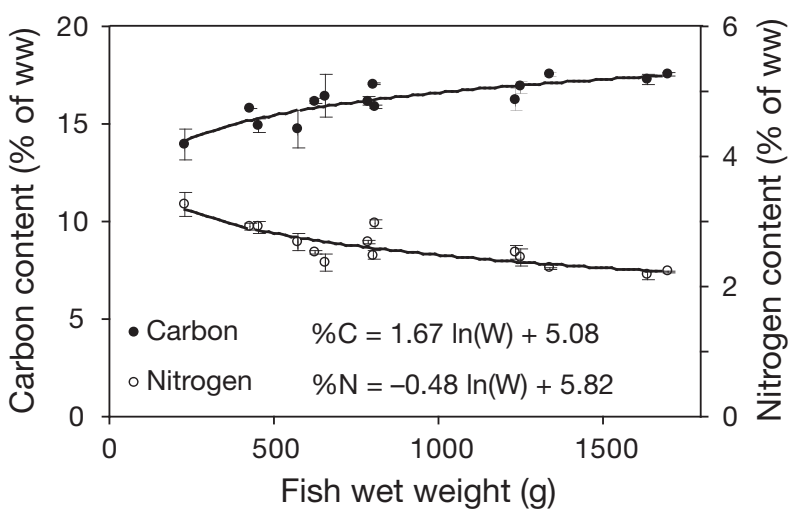

Fig. 3. Carbon and nitrogen content of rainbow trout relative to fish total weight including gut content (W). Values presented as mean \pm SE of 3 subsamples from each individual. $\mathrm{r}^{2}=0.779$ for carbon and 0.783 for nitrogen $i \mathrm{p}<0.0005$ for both relations it ranged between 0.1 and $14.2 \mathrm{~cm} \mathrm{~s}^{-1}$, with an average $( \pm \mathrm{SD})$ of $4.2 \pm 4.4 \mathrm{~cm} \mathrm{~s}^{-1}$. The dominant current direction at the farming site was into the fjord from the sound (Table 2).

DO at $5 \mathrm{~m}$ depth at the farm site was usually supersaturated and within $\pm 8 \%$ of the DO concentration at the reference station (Fig. 4a). However, from July to midSeptember 2006 the oxygen concentration at the farm site was 11 to $26 \%$ lower than levels at the reference station. This coincided with the highest measured ammonium concentration in the surface water at the fish farm (Fig. 4b). While both the farm site and the reference station showed similar ammonium concentrations when there was no farming, in periods with active farming, the ammonium concentration at the fish farm was on average $3.9 \pm 1.2 \mu \mathrm{M}$ higher than at the reference station, Generally, however, the relationship was weak $\left(\mathrm{r}^{2}=0.28\right.$, linear regression) between feeding activity and ammonium concentration in the upper water column. Nitrate concentrations in the surface water did not differ significantly between the 2 sites (Fig. 4c).

In bottom waters, DO, ammonium and nitrate concentrations were similar between the 2 sites (Fig. 4). During summer 2006, a weak thermocline was found at $\sim 40 \mathrm{~m}$ depth, and consequently the DO concentration in the bottom water at both stations decreased to a minimum of $48 \%$ of air saturation and the ammonium concentration increased (Fig. 4d,e). The decrease in bottom water nitrate concentration during summer (Fig. 4f) was due to decreased nitrate content in inflowing water from the sound outside the fjord (data not shown).

Despite higher nutrient availability at the farm site, chl a concentration, algal composition and primary production showed no local productivity increase (Fig. 5). Annual primary production at the farming site was $352 \mathrm{gC} \mathrm{m}^{-2}$, while the corresponding value for the reference station was $335 \mathrm{gC} \mathrm{m}^{-2}$.

\section{Sediment description}

Prior to initiating farming activities, the sediment at the 2 sampling sites was sampled and found to be similar in physical and chemical characteristics (Table 1).

Table 2. Mean, maximum and residual current velocities and their direction at 3 depths close to the farming site

\begin{tabular}{|c|c|c|c|c|c|}
\hline \multirow{2}{*}{$\begin{array}{l}\text { Depth } \\
\text { (m) }\end{array}$} & \multirow[b]{2}{*}{ Mean } & \multicolumn{3}{|c|}{ Velocity $\left(\mathrm{cm} \mathrm{s}^{-1}\right)$} & \multirow{2}{*}{$\begin{array}{c}\text { Residual } \\
\text { dir. }\left({ }^{\circ}\right)\end{array}$} \\
\hline & & Max. & $\mathrm{SD}$ & Residual & \\
\hline 6 & 5.7 & 18.2 & 5.7 & 4.9 & 287 \\
\hline 26 & 4.3 & 12.2 & 4.4 & 3.5 & 270 \\
\hline 44 & 4.2 & 14.2 & 4.4 & 2.3 & 290 \\
\hline
\end{tabular}




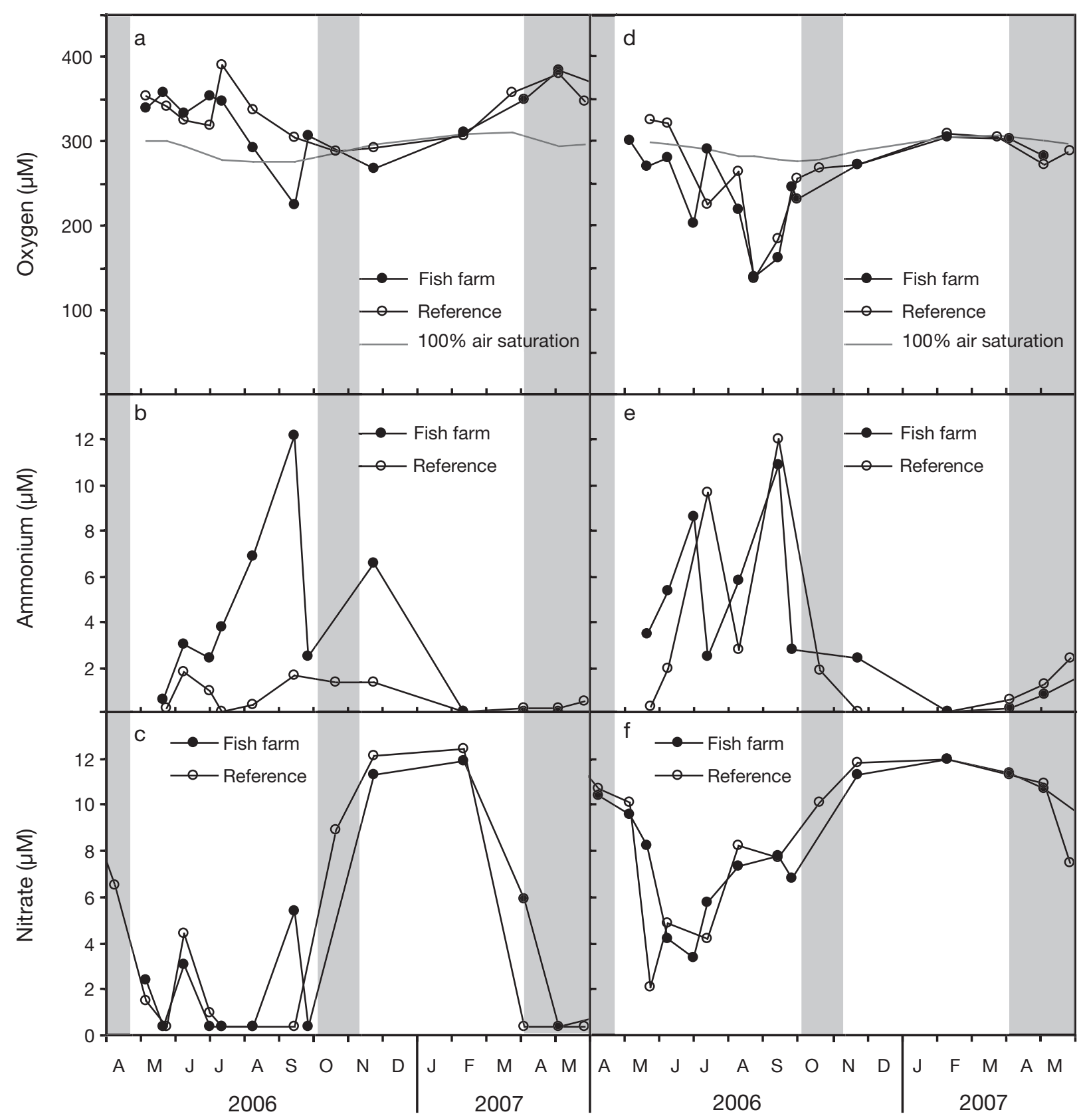

Fig. 4. $(\mathrm{a}, \mathrm{d})$ Oxygen, $(\mathrm{b}, \mathrm{e})$ ammonium and $(\mathrm{c}, \mathrm{f})$ nitrate concentration in $(\mathrm{a}, \mathrm{b}, \mathrm{c})$ surface waters, and $(\mathrm{d}, \mathrm{e}, \mathrm{f})$ bottom waters at fish farm and reference station. Grey lines in $(\mathrm{a}, \mathrm{d})$ represent oxygen concentration of $100 \%$ air-saturated water at given salinities and temperatures. Vertical grey zones indicate periods with no farming activity. SD on duplicate measurements not included since error bars in most cases were smaller than symbol size. Data on reference station from Gaard et al. (2011)

Farming activity appeared immediately to change this. First, distinct faecal pellets (and occasional feed pellets) were observed, along with patches of the sulphur bacteria Beggiatoa spp. (Jørgensen \& Revsbech 1983). Later the whole sediment surface at the farm site became covered with mats of Beggiatoa spp., and the underlying sediment turned black. The black zone, at first noted at the top of the sediment, progressed downward as farming activity continued, with faecal pellets spreading sporadically throughout the black layer. In August the sediment was black to the maximum sampling depth of $>18 \mathrm{~cm}$, and gas bubbles were observed from $\sim 6 \mathrm{~cm}$ on down. In early November 2006, following $39 \mathrm{~d}$ of no farming activity, the sediment exhibited signs of recovery, becoming light grey to a depth of $\sim 1 \mathrm{~cm}$, but remaining black in the deeper 


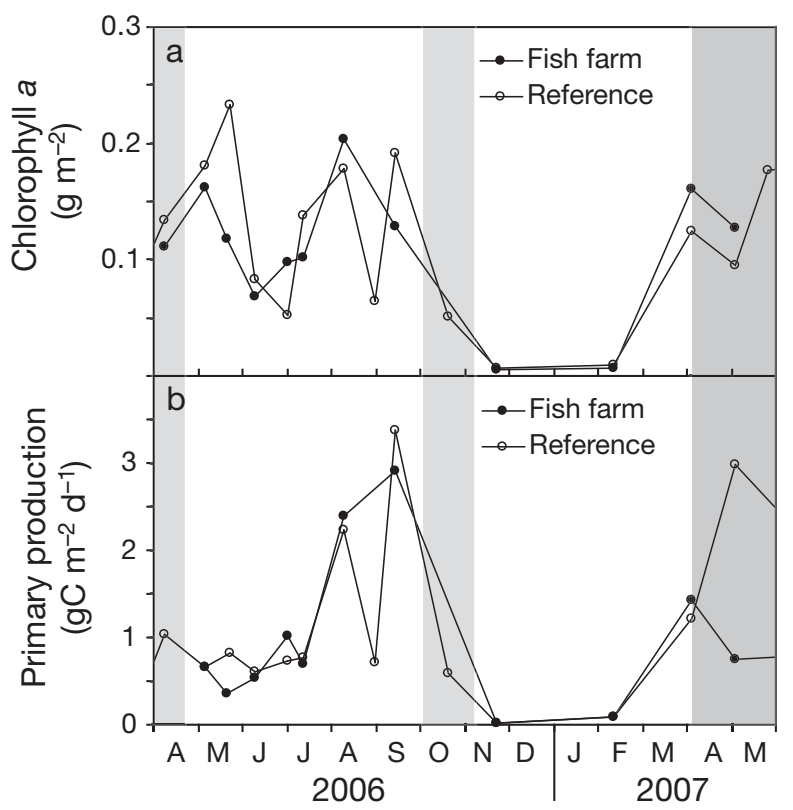

Fig. 5. (a) Chl a content (from 0-20 $\mathrm{m}$ depth), and (b) primary production at fish farm and reference station. Vertical grey zones indicate periods with no farming activity. Data on reference station from Gaard et al. (2011)

layers. Burrowing fauna, dominated by the $\mathrm{H}_{2} \mathrm{~S}$-tolerant polychaete Capitella capitata, was observed in the cores, but the burrow sides still hosted Beggiatoa spp. On 5 December 2006, <1 mo after farming activity was resumed, the sediment again appeared highly impacted. The surface was again covered by Beggiatoa spp., the sediment was black down to $12 \mathrm{~cm}$, and gas bubbles reappeared from $\sim 6 \mathrm{~cm}$ depth downwards. In April and May 2007, after 2 mo with a low feeding rate and then cessation of farming activity, the sediment showed improvement similar to what had been observed in November 2006.
Prior to commencement of farming activity the oxygen penetration depth into the sediment varied, but the average penetration depth was $>3 \mathrm{~mm}$ (Fig. 6a). During farming, DO microprofiles became less variable, with oxygen penetration depth $<0.2 \mathrm{~mm}$ (Fig. 6a). However, during October 2006, when no farming activities were being conducted, conditions improved substantially, and after $39 \mathrm{~d}$ without farming the oxygen penetration had increased to $1.3 \pm 0.1 \mathrm{~mm}$ (Figs. 6a \& 7a). Some increase of the oxygen penetration depth was likewise observed in April and May 2007 when farming activity had stopped, although not at the same magnitude as during the recovery event in October-November 2006 (Fig. 7a).

Sediment OC content also exhibited significant changes in relation to farming activity. Prior to initiation of farming activity, the average OC content was $1.8 \mathrm{mmolC} \mathrm{g}^{-1}$ (dry wt, top $12 \mathrm{~cm}$ ), a value which held relatively constant down through the sediment (Fig. 6b). After 4 mo of fish farming, the sediment was highly enriched with OC. The average OC content in the upper $4 \mathrm{~cm}$ at this time was $4.9 \pm 1.2 \mathrm{mmolC} \mathrm{g}^{-1}$ (dry wt), and the sediment remained enriched in OC during farming activity. After $39 \mathrm{~d}$ without farming activity, the OC content of the sediment decreased substantially, and elevated OC content was observed only in the top $2 \mathrm{~cm}$ of the sediment layer, but when farming was re-established OC content began to increase again. The $\mathrm{C}: \mathrm{N}$ ratio showed a similar trend, with elevated values during farming periods and declining values in periods with reduced or no farming activity (Fig. 6c).

Total and diffusive oxygen uptakes at the farm site generally reflected a similar pattern and were of similar magnitude at all times (Fig. 7b), indicating that fauna irrigation contributed only marginally to benthic solute exchange. Oxygen uptake increased with increasing
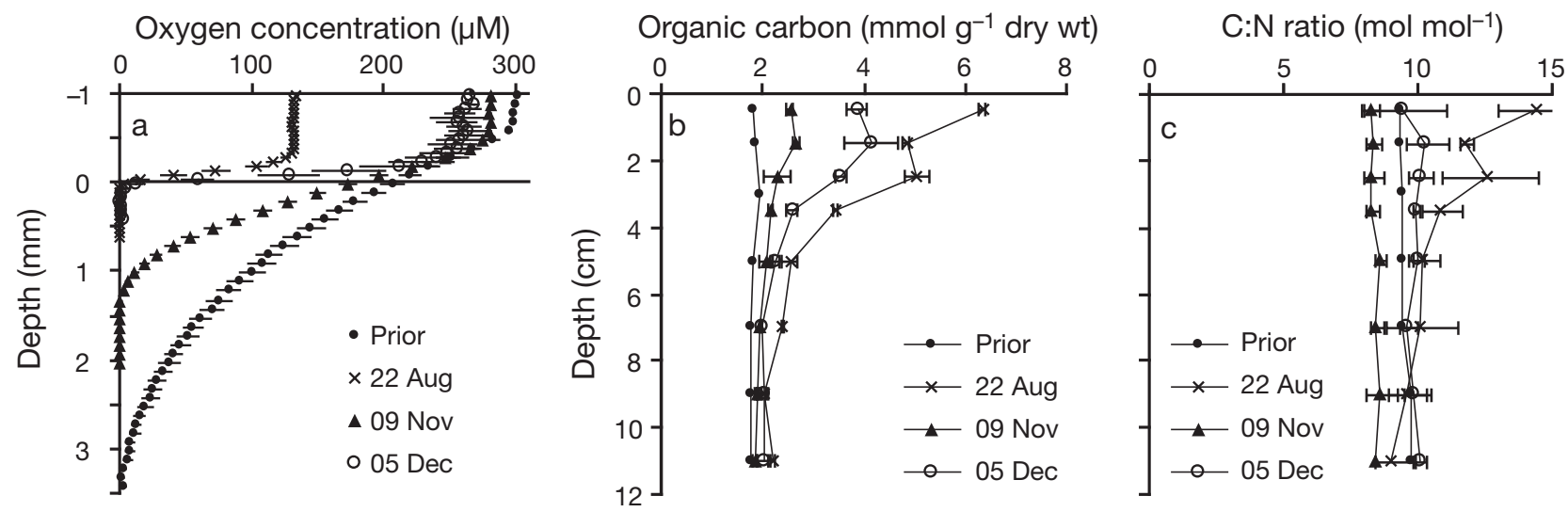

Fig. 6. (a) Oxygen microprofiles as mean $( \pm \mathrm{SE})$ of $7-9$ profiles in 3 cores, (b) carbon content as mean $( \pm \mathrm{SD})$ of 2 cores, and (c) C:N ratio as mean $( \pm \mathrm{SD})$ of 2 cores for 4 sampling dates in 2006: prior to farming, after $\sim 4$ mo of active farming (22 August), after $39 \mathrm{~d}$ without farming activity ( 9 November), and 1 mo after re-establishment of farming (5 December). Points lacking error bars indicate non-replicated samples 


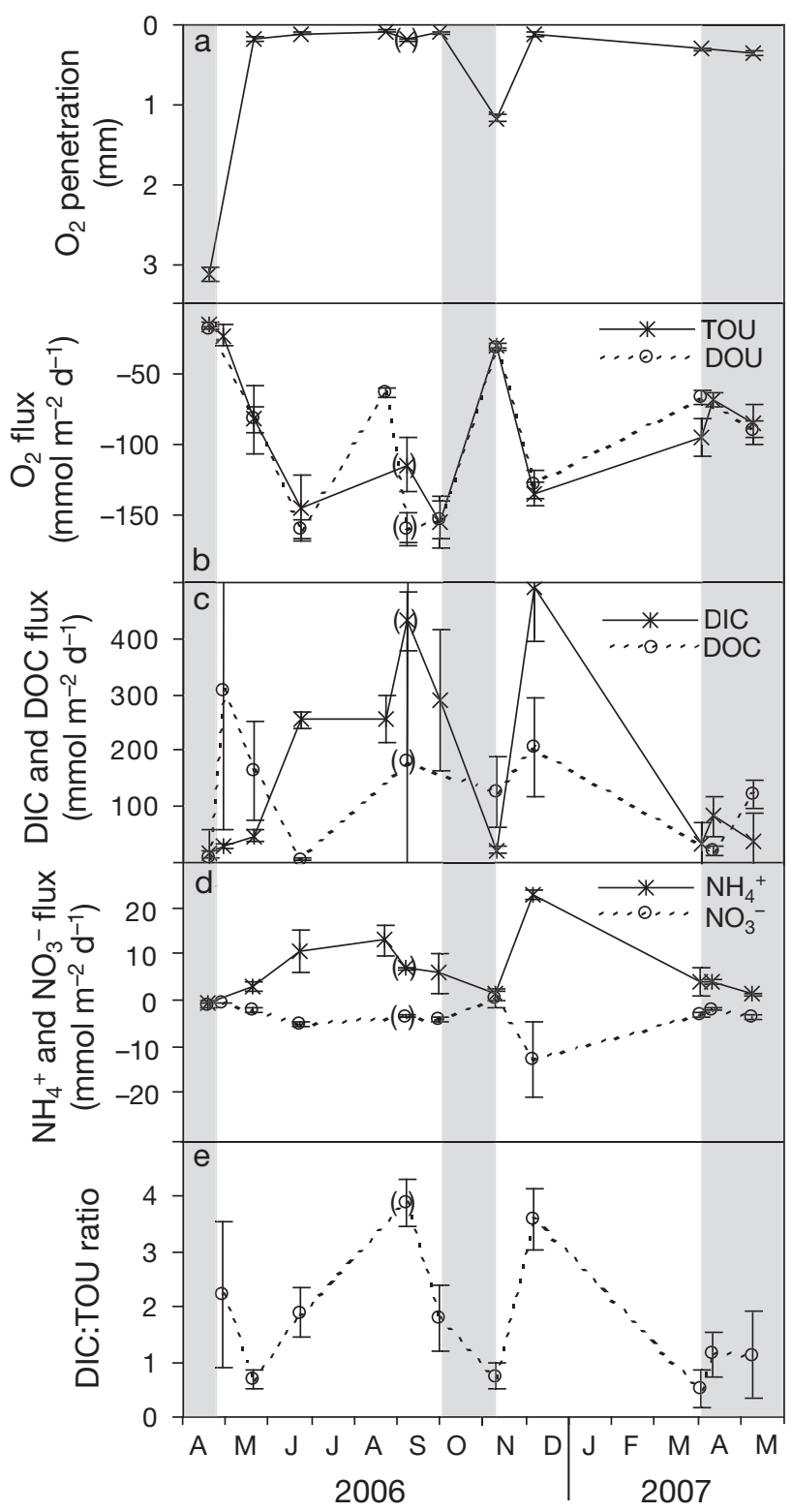

Fig. 7. Time series of (a) oxygen penetration depth into sediment, $(b, c, d)$ sediment water exchange rates for several variables (DOC: dissolved organic carbon), and (e) ratio between dissolved inorganic carbon (DIC) efflux and total oxygen uptake (TOU) at farming site from April 2006 to May 2007. Negative fluxes represent sediment uptake. Error bars indicate SE. For oxygen penetration depth and diffusive oxygen uptake (DOU), $n=9$; for other measurements, $n=3$. Fluxes measured on September 7 (indicated with parentheses) were incubated with $100 \%$ air-saturated seawater although, in situ, bottom water was only $50 \%$ saturated. Vertical grey zones indicate periods with no farming activity

farming activity, in June 2006 reaching a maximum of $160 \pm 7 \mathrm{mmol} \mathrm{m}^{-2} \mathrm{~d}^{-1}$. In August the oxygen uptake transiently decreased, presumably due to reduced DO ( $50 \%$ of air saturation) in the bottom water, limiting the potential high oxygen uptake rate of the carbon- enriched sediment. After the October recovery period the oxygen uptake was only $30 \pm 4.5 \mathrm{mmol} \mathrm{m}^{-2} \mathrm{~d}^{-1}$, increasing to the former level when farming was reestablished (Fig. 7b). Similar trends were also observed in DIC flux (Fig. 7c). DIC efflux was, however, markedly higher than oxygen uptake in the sediment, and this difference increased with increasing exchange rates (Fig. 7e). During the entire measuring period of 387 d (linear integration between measuring points), the total oxygen uptake was $40.6 \mathrm{~mol} \mathrm{~m}^{-2}$, while the DIC efflux was twice as high, viz. $81.7 \mathrm{molC} \mathrm{m}^{-2}$. DOC flux was highly variable, both in time and between replicate measurements (Fig. 7c), and did not show similar development over time as the other parameters, but in all measurements there was an efflux of DOC from the sediment, which, integrated over the entire study period, amounted to $43.4 \mathrm{molC} \mathrm{m}^{-2}$.

An $\mathrm{NH}_{4}{ }^{+}$efflux from the sediment was evident at all times, increasing with increasing DIC release rate (Fig. 7). The $\mathrm{C}: \mathrm{N}$ ratio of the measured effluxing solutes was $70 \pm 20$, while the $\mathrm{C}: \mathrm{N}$ ratio of the settling material was $11 \pm 1$. This apparent mismatch could be related to (1) denitrification/anammox activity, (2) release of dissolved organic nitrogen (DON) or (3) preferential nitrogen incorporation into bacterial biomass. There was almost always a sediment uptake of $\mathrm{NO}_{3}{ }^{-}$ (from 0.46 to $12.2 \mathrm{mmol} \mathrm{m}^{-2} \mathrm{~d}^{-1}$ ). Two exceptions were during the October 2006 recovery period, with a release of $0.86 \pm 0.09 \mathrm{mmol} \mathrm{m}^{-2} \mathrm{~d}^{-1}$, and at the very beginning of the farming season when the release was $0.22 \pm 0.03 \mathrm{mmol} \mathrm{m}^{-2} \mathrm{~d}^{-1}$.

\section{Benthic footprint of farming activity}

Sediment was visibly impacted $30 \mathrm{~m}$ from the farm along the transects. Within this distance, the sediment was black and the surface was covered by Beggiatoa spp. At $60 \mathrm{~m}$ distance, the only visible farming impact was that the top $3 \mathrm{~cm}$ of the sediment were slightly darker than at the reference station. Sediment at both sites contained macrofauna, although the composition differed between sites: the dominant fauna at the farm site was Capitella capitata, while the reference station was dominated by the bivalves Abra nitida and Thyasira flexuosa. At $90 \mathrm{~m}$ distance from the farm no signs of farming activity were observed.

The oxygen concentration in the sediment reflected the organic load. Within $20 \mathrm{~m}$ of the fish farm, the oxygen concentration changed rapidly in the diffusive boundary layer, and at the sediment surface the oxygen concentration was $<10 \mu \mathrm{M}$ (Fig. 8a,b). The oxygen penetration into the sediment increased with increasing distance from the farm, from $<0.2 \mathrm{~mm}$ below the farm to $1.7 \pm 0.1 \mathrm{~mm}$ at $90 \mathrm{~m}$ distance. At the reference 

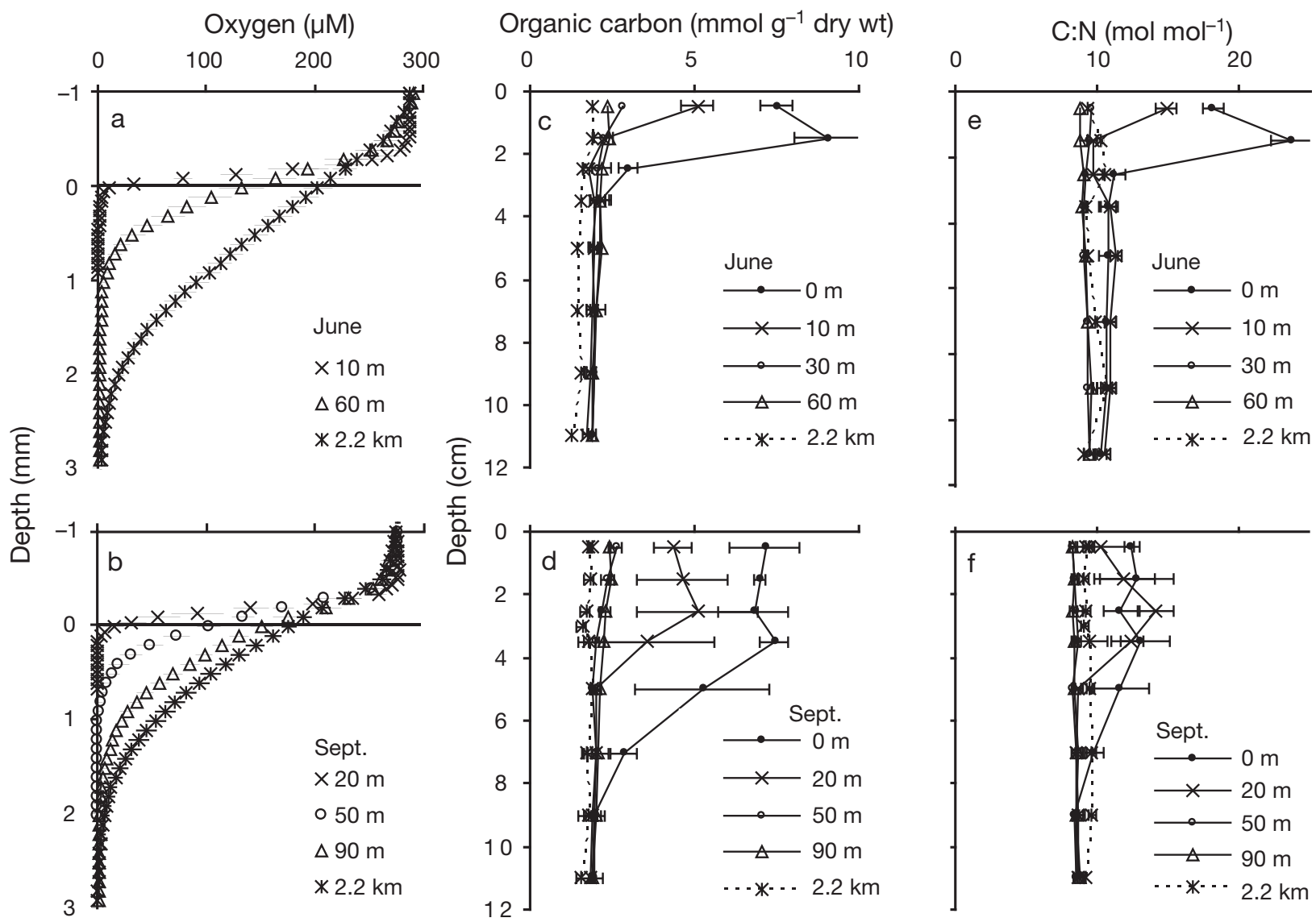

Fig. 8. Sediment characteristics at various distances from fish farm on (a,c,e) 22 June, and (b,d,f) 7 September 2006 . Oxygen microprofiles presented as mean $\pm \mathrm{SE}$ of $7-9$ profiles in 3 cores, carbon content as mean of 2 cores $\pm \mathrm{SD}$, and C:N ratio as mean \pm $\mathrm{SD}$ of 2 cores. Points lacking error bars indicate non-replicated samples

station oxygen reached more than $2.5 \mathrm{~mm}$ into the sediment (Fig. 8b).

The OC content of the sediment was highest at the surface and decreased with sediment depth and distance from the fish farm (Fig. 8c,d). On 22 June 2006 the average $\mathrm{OC}$ of the top $3 \mathrm{~cm}$ of the sediment was $6.5 \mathrm{mmolC} \mathrm{g}^{-1}$ (dry wt), while the content of the deeper sediment was $2.0 \mathrm{mmolC} \mathrm{g}^{-1}$ (dry wt). At $10 \mathrm{~m}$ from the farm the upper $2 \mathrm{~cm}$ showed an average OC content of $3.7 \mathrm{mmolC} \mathrm{g}^{-1}$ (dry wt) (Fig. 8c), and at $30 \mathrm{~m}$ distance only the upper $1 \mathrm{~cm}$ exhibited elevated levels of OC (2.8 $\mathrm{mmolC}^{-1}$ dry wt). At a distance of $60 \mathrm{~m}$ the OC content was fairly constant with depth and resembled conditions at the reference station. However, during the $77 \mathrm{~d}$ that separated measurements along the 2 transects the profiles of OC content changed considerably, reflecting a continuous accumulation of OC near the fish farm (Fig. 8c,d). The C:N ratio of the sediment showed a similar pattern, with an elevated C:N ratio in sediment affected by farming activity (Fig. 8e,f).

Sedimentation measurements were conducted only along the second transect, although the feeding rates were fairly similar when each transect was sampled (Fig. 2a). During measurements along the second transect the feeding rate was $430 \mathrm{gC} \mathrm{m}^{-2} \mathrm{~d}^{-1}$, and the vertical carbon flux (POC) below the farm at 20 and $40 \mathrm{~m}$ depth was 4.3 and $4.9 \mathrm{~g} \mathrm{~m}^{-2} \mathrm{~d}^{-1}$, respectively (Fig. 9a). The POC flux decreased rapidly within $20 \mathrm{~m}$ of the farming site. At this distance from the site, at 20 and $40 \mathrm{~m}$ depth, it was 0.4 and $1.2 \mathrm{~g} \mathrm{~m}^{-2} \mathrm{~d}^{-1}$, respectively. At $90 \mathrm{~m}$ from the farm site it was only slightly higher than at the reference station. The C:N ratio of the sinking material showed a similar trend, with decreasing ratio with distance from the farm; at $90 \mathrm{~m}$ distance it was only slightly higher than at the reference station.

Like oxygen penetration depth (Figs. 8a,d \& 9b), DOU decreased rapidly with distance from the farm, while TOU remained fairly constant within $90 \mathrm{~m}$ of the fish farm. Thus the difference between TOU and DOU increased with distance, reflecting higher faunal activity further away from the farm (Fig. 9c). Oxygen fluxes and penetration depth were similar at the 2 transects (Fig. 9b,c). However, the DIC flux in the vicinity of the farm increased considerably between the 2 sampling 


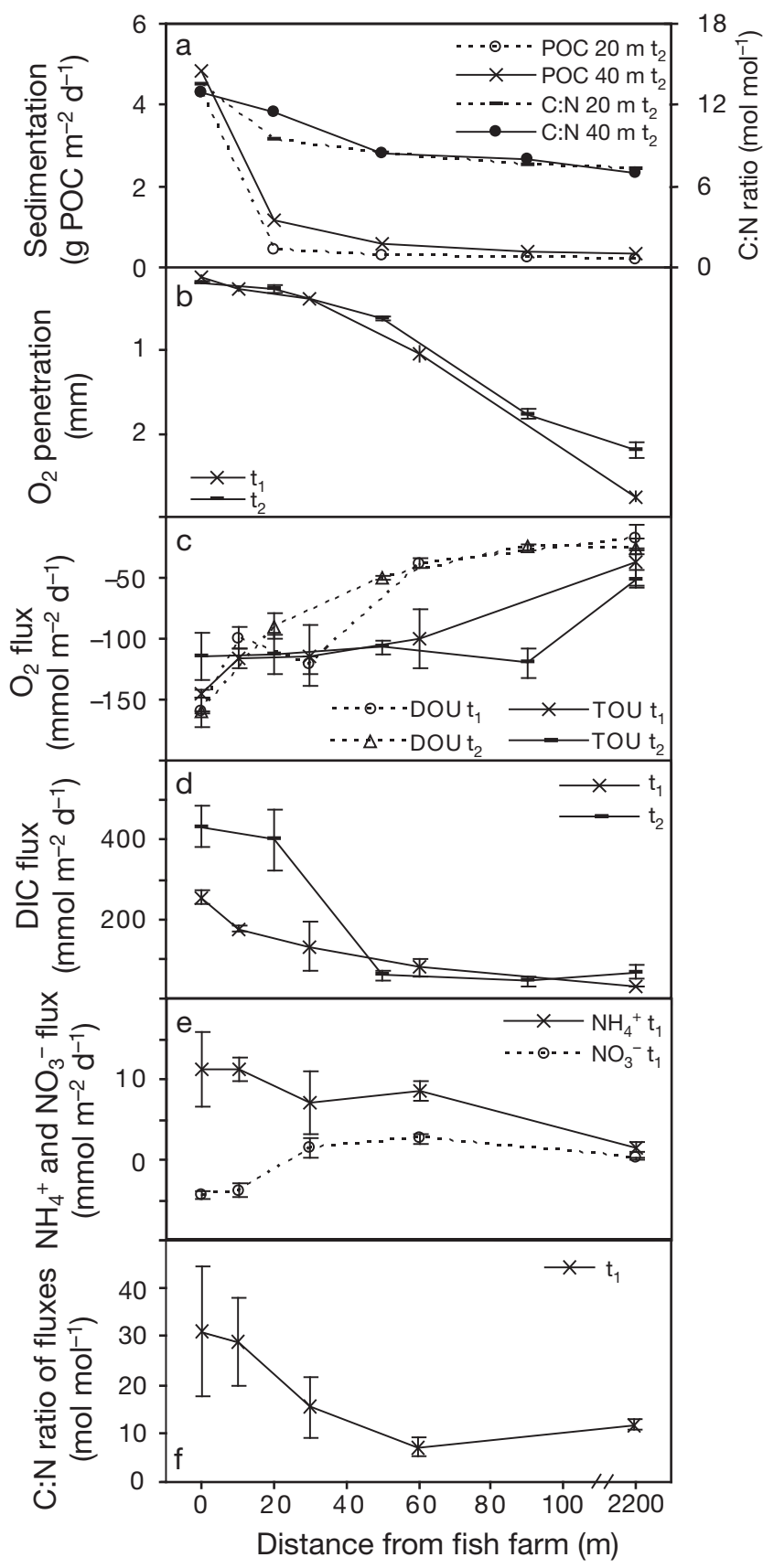

Fig. 9. Measurements along transect of (a) POC sedimentation and $\mathrm{C}: \mathrm{N}$ ratio of sedimenting material, (b) oxygen penetration depth into sediment, $(\mathrm{c}, \mathrm{d}, \mathrm{e})$ sediment water exchange rates for several variables, and (f) ratio between DIC and DIN effluxes at various distances from the fish farm on 22 June $2006\left(t_{1}\right)$ and 7 September $2006\left(t_{2}\right)$. Abbreviations as in Fig. 7. Negative fluxes represent sediment uptake. Error bars indicate SE. For oxygen penetration depth and DOU, $\mathrm{n}=9$; for other measurements, $n=3$

dates (Fig. 9d). On 22 June 2006 the DIC flux was $255 \pm$ $16 \mathrm{mmol} \mathrm{m}^{-2} \mathrm{~d}^{-1}$ at the farming site, and it decreased exponentially with distance. Seventy-seven days later DIC was $432 \pm 52 \mathrm{mmol} \mathrm{m}^{-2} \mathrm{~d}^{-1}$ at the farm, decreasing to $399 \pm 79 \mathrm{mmol} \mathrm{m}^{-2} \mathrm{~d}^{-1} 20 \mathrm{~m}$ from the farm, and dropping to $58 \pm 12 \mathrm{mmol} \mathrm{m}^{-2} \mathrm{~d}^{-1} 50 \mathrm{~m}$ from the farm. The ratio between DIC efflux and TOU at the farming site increased from 1.8 to 3.8 in the 77 days between the 2 transect measurements. On 22 June 2006 the ammonium efflux decreased slightly with distance, from $11.3 \pm 4.6 \mathrm{mmol} \mathrm{m}^{-2} \mathrm{~d}^{-1}$ at the farm to $8.6 \pm 1.2 \mathrm{mmol}$ $\mathrm{m}^{-2} \mathrm{~d}^{-1} 60 \mathrm{~m}$ away; sediment ammonium release at the reference station was $1.5 \pm 0.6 \mathrm{mmol} \mathrm{m}^{-2} \mathrm{~d}^{-1}$ (Fig. 9e) The nitrate flux changed from a sediment uptake of $4.4 \pm 0.5 \mathrm{mmol} \mathrm{m}^{-2} \mathrm{~d}^{-1}$ at the farming site to an efflux of $2.6 \pm 0.5 \mathrm{mmol} \mathrm{m}^{-2} \mathrm{~d}^{-1} 60 \mathrm{~m}$ away. At the reference station there was a small nitrate efflux of $0.2 \pm 0.1 \mathrm{mmol}$ $\mathrm{m}^{-2} \mathrm{~d}^{-1}$. The C:N ratio of the DIC and DIN effluxes decreased rapidly from $30 \pm 17$ at the farm to $6.9 \pm 1.8$, $60 \mathrm{~m}$ from the farm. These values are comparable to the C:N ratio of the sedimenting material (Fig. 9).

\section{DISCUSSION}

\section{Effect of farming activity on water column}

From July to mid September the DO concentration at the farming site was 11 to $26 \%$ lower than at the reference station (Fig. 4a). This offset was not caused by differences in primary production, which was the same at the 2 sites (Fig. 5), but may rather be ascribed to localized respiration of the fish. An estimate based on temperature-corrected respiration rates for medium-sized Salmo salar swimming $0.75 \mathrm{bl} \mathrm{s}^{-1}$ (Grøttum \& Sigholt 1998) amounted to an oxygen requirement of the fish stock on the order of 360 and $740 \mathrm{~mol} \mathrm{~h}^{-1}$ for June and September, respectively. In order to maintain the measured DO concentration in the cages, ambient current velocities in the range of 0.2 to $0.5 \mathrm{~cm} \mathrm{~s}^{-1}$ were required, assuming that current velocity is reduced by 10 to $35 \%$ during passage through the net (Pillay 2004, Patursson et al. 2010). Current velocities below $2 \mathrm{~cm}$ $\mathrm{s}^{-1}$ were measured only $6.5 \%$ of the time during March and April 2006. During summer, lower current velocities might prevail but apparently they remained sufficient to counteract any severe DO depletion within or around the farm (Fig 4a).

Ammonium is the main dissolved nutrient excreted from farmed fish; concentrations of other nutrients (e.g. nitrate, phosphate) apparently remain unaffected by farming activity (Brooks \& Mahnken 2003, Sanderson et al. 2008). In the present study, the average ammonium concentration during farming activity was $4.0 \pm 1.3 \mu \mathrm{M}$, which is 4.3 times higher than at the reference station. The highest ammonium concentration $(12.4 \mu \mathrm{M})$ was observed at the same time as the minimum DO concentration $(224.6 \mu \mathrm{M}, 81 \%$ saturation), indicating a transiently lower water exchange 
during the measurements. Generally, ammonium concentrations at fish farms reach values of 2 to $10 \mu \mathrm{M}$ (Pitta et al. 2006, 2009, Sanderson et al. 2008), even at sites with relatively efficient water exchange (Merceron et al. 2002). However, in agreement with most studies (Brooks \& Mahnken 2003, Islam 2005, Pitta et al. 2006), we did not see any localized stimulation of primary production (Fig. 5).

The flushing time through the farm was about $6 \mathrm{~min}$, while the specific primary production at the site implies an average phytoplankton doubling time of $2 \mathrm{~d}$ (Gaard et al. 2011). Thus no local effects would be expected. This supports the conclusion by Brooks \& Mahnken (2003) that the time required for phytoplankton cells to divide implies that the cells will be transported away from the nutrient point source before any local growth response can be detected. This makes it difficult to detect the possible effect on primary production from point sources in open-water bodies. However, on regional scales, farming may affect primary production depending on e.g. hydrographic features and nutrient status in the euphotic zone (see 'Carbon and nitrogen budget for the fish farm').

\section{Effects of farming activity on benthic mineralization rates}

There was an obvious accumulation of particulate wastes below the fish farm (Fig. 6), leading to reduced oxygen penetration and elevated benthic solute exchange rates, both reflecting the stimulated mineralization rates (Fig. 7).

The benthic mineralization rate below the fish farm was controlled by the input of particulate organic wastes from farming activity, and apparently did not reach a saturation level, as has been observed in studies with an even higher carbon load (Holmer et al. 2003). The ratio between DIC efflux and TOU increased dramatically with the organic loading. This reflected increasing accumulation of anaerobic metabolites (viz. FeS, $\mathrm{FeS}_{2}$ and even $\mathrm{H}_{2} \mathrm{~S}$ and $\mathrm{CH}_{4}$ in the form of bubbles) that are not being oxidized by the limited oxygen supply (Hall et al. 1990, Findlay \& Watling 1997, Holmer et al. 2002, 2003). We cannot exclude a minor contribution to DIC from enhanced dissolution of shell debris in the reduced sediments. During active farming, the sediment was covered by Beggiatoa spp., and the oxygen penetration depth was $<200 \mu \mathrm{m}$. Thus at this point most sediment oxygen uptake was presumably for oxidation of reduced chemical species produced during anaerobic bacterial reduction (e.g. sulphide) rather than for aerobic heterotrophic activity (Jørgensen 1982). The similarity between DOU and TOU (Fig. 7b) below the farm implies little active macrofauna; it also implies that oxygen is supplied to the sediment mainly by diffusion (Glud et al. 2003).

On average, the DOC efflux amounted to $53 \%$ of the DIC release rate, which is higher than the 10 to $20 \%$ generally encountered in coastal and shelf sediments (Hall et al. 1990, Viollier et al. 2003). However, the importance of DOC release has been found to increase with the reducing state of the sediment, mainly as a result of incomplete oxidation, as respiration processes struggle to keep up with hydrolysis and fermentation (Hansen \& Blackburn 1991). DOC efflux has also been found to increase in importance when the material is degraded close to the sediment surface (Blackburn \& Blackburn 1993, Blackburn et al. 1996, Hulth et al. 1997, Fenchel et al. 2000). In the present study, the sediment was highly reduced and enriched with $\mathrm{OC}_{\text {, }}$ and consequently macrofauna was absent or scarce (Table 1). Thus a potentially large portion of the POM was mineralized close to the sediment surface, leading to high DOC effluxes. In fact DOC release may be a more important pathway for benthic carbon release below aquaculture farms than previously thought.

Nitrate uptake of the sediment increased linearly with increasing mineralization rates $\left(\mathrm{r}^{2}=0.62, \mathrm{p}<\right.$ 0.005). Since the carbon-enriched sediment was covered with Beggiatoa spp. during active farming, some of this nitrate uptake may be attributable to intercellular bacterial storage (McHatton et al. 1996). However, stimulated denitrification or dissimilatory nitrate reduction to ammonia (DNRA) in carbon-enriched, oxygen-depleted sediment below fish farms has also been documented (Christensen et al. 2000, Holmer et al. 2003). The strong correlation $\left(\mathrm{r}^{2}=0.76, \mathrm{p}<0.0005\right)$ between nitrate uptake and ammonium release could indeed indicate a dominant role for DNRA (Nishio et al. 1983, Christensen et al. 2000, Gardner \& McCarthy 2009). Overall, the sediment served as a source of dissolved nitrogen, but our nitrogen release rates do not reflect the total mineralization of nitrogen, which could also be released as DON or $\mathrm{N}_{2}$, pathways we did not investigate in the present study. The high $\mathrm{C}: \mathrm{N}$ ratio $(70 \pm 20)$ of measured effluxing solutes below the fish farm indicates that some other form of nitrogen release might be quantitatively important. Indeed, DON appears to be the dominant form of nitrogen released from organic-enriched sediments (Hall et al. 1992, Blackburn \& Blackburn 1993, Sloth et al. 1995, Blackburn et al. 1996, Fenchel et al. 2000).

\section{Carbon and nitrogen budget for the fish farm}

To establish an overall budget for carbon and nitrogen flow through the farming area we focused on the $77 \mathrm{~d}$ between the 2 transect measurements (from 
22 June to 7 September 2006). During this period sediment traps were deployed 5 times, and the data were complemented by detailed mapping of carbon and nitrogen enrichments in the sediment.

The total carbon and nitrogen input with fish feed in the period of interest was $62.7 \mathrm{t}$ carbon and $9.5 \mathrm{t}$ nitrogen (Fig. 10). The average fish weight increased from 240-280 to 600-950 g, with a total fish biomass increase (including dead fish) of $123 \mathrm{t}$, amounting to a carbon and nitrogen incorporation of 20.8 and $3 \mathrm{t}$, respectively.

The inorganic carbon excretion from the fish was estimated from oxygen consumption of Salmo salar correlated to weight, temperature and swimming speed (Grøttum \& Sigholt 1998), and from the respiration quotient of 0.8 presented by Forsberg (1997). Assuming an average swimming speed of 0.5 to $1.0 \mathrm{bl}$ $\mathrm{s}^{-1}$ (Juell 1995, Cooke et al. 2000), the total inorganic carbon release in the $77 \mathrm{~d}$ was from 33 to $44 \mathrm{t}$ (Fig. 10). Most probably there is an additional carbon release to the water column in the form of organic solutes lost from sinking food and faecal pellets (Chen et al. 1999, Fernandez-Jover et al. 2007).

The impacted sediment area was estimated from the sediment exhibiting elevated diagenetic activity along the transects, and from current speed and direction. An oval benthic footprint was suggested, with the longer axis lying parallel to the transect (Fig. 1, Table 2). The oxygen penetration depth was approximated by an exponential increase with distance from the farm along the 2 transects $\left(r^{2}=0.95\right.$ and 0.99); the DOU was also approximated well with an exponential decline $\left(\mathrm{r}^{2}=0.88\right.$ and 0.99). Likewise, DIC fluxes decreased exponentially with distance in the first transect $\left(r^{2}=0.98 ;\right.$ Fig. 9). These exponential extrapolations predicted that reference conditions were reached at a distance of 85 to $93 \mathrm{~m}$ and 99 to $103 \mathrm{~m}$ from the farm along transects $t_{1}$ and $t_{2}$, respectively.

The accumulation of farm-derived OC and nitrogen in the sediment was estimated from the OC and nitrogen that had accumulated in sediment during the period between the 2 transect measurements. The area-based amount of $\mathrm{OC}$ and nitrogen $\left(\mathrm{mmol} \mathrm{m} \mathrm{m}^{-2}\right)$ was obtained from the content per unit dry wt of sediment (Fig. 8), and the density and water content of the sediment. The total accumulation in the footprint area was subsequently determined, assuming that the content in the sediment below the cage was represented by the measurement at the edge of the cage, while measurements along the transect represented content at various distances from the farm.

Approx. $32 \%$ of the OC and nitrogen that had accumulated in the sediment was found directly below the $\sim 2000 \mathrm{~m}^{2}$ fish farm, while the remaining OC and nitrogen was located elsewhere in the footprint area. Correspondingly $31 \%$ of the DIC efflux from mineralization of fish farm wastes occurred directly below the fish cages. Due to lack of DOC measurements along the transects, it was assumed that DOC was proportional to DIC release rates, amounting to $53 \%$ of DIC efflux
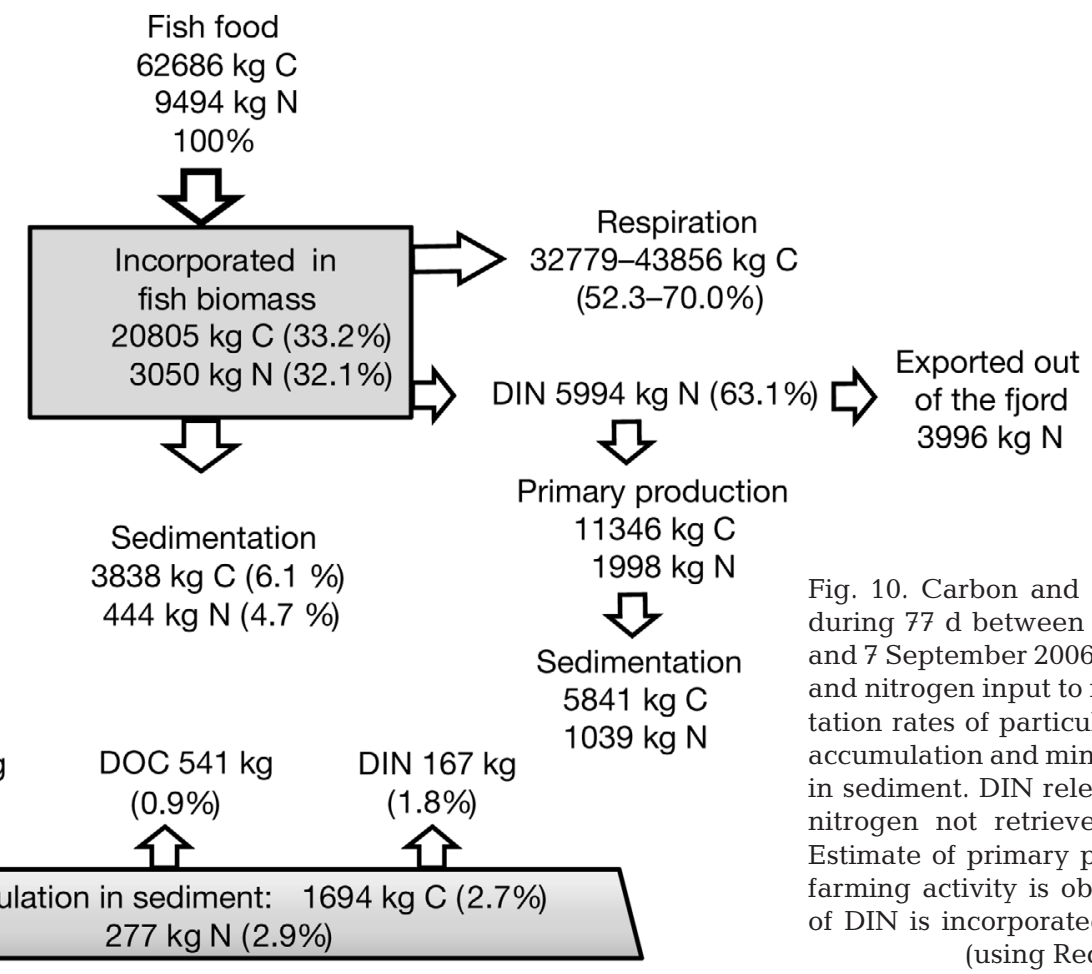

Fig. 10. Carbon and nitrogen budget for fish farm during $77 \mathrm{~d}$ between sampling 2 transects (22 June and 7 September 2006). Percentages are \% of carbon and nitrogen input to farm in form of feed. Sedimentation rates of particulate farm wastes are based on accumulation and mineralization of $\mathrm{OC}$ and nitrogen in sediment. DIN release from farm is calculated as nitrogen not retrieved in biomass and sediment. Estimate of primary production based on DIN from farming activity is obtained by assuming one-third of DIN is incorporated into phytoplankton biomass (using Redfield ratio of C:N) 
as measured directly below the farm. Only $10 \%$ of total DIN efflux occurred directly below the fish cages, with a much larger percentage occurring over the rest of the footprint. This was to a large extent due to the change from high-nitrate sediment uptake at the fish farm to nitrate release at some distance from the farm (Fig. 9e). It must be emphasized, however, that the benthic nitrogen budget does not account for DON exchange, denitrification or anammox.

During the $77 \mathrm{~d}$ between transect measurements, total OC accumulation in the footprint area was $1694 \mathrm{~kg}$, and total nitrogen $227 \mathrm{~kg}$. Total mineralization of carbon to DIC was $1603 \mathrm{~kg}$, while carbon leaving the sediment as DOC amounted to $541 \mathrm{~kg}$ (Fig. 10). The DIN efflux was $167 \mathrm{~kg}$. This suggests that the total $\mathrm{OC}$ and nitrogen sedimentation was at least $3838 \mathrm{~kg}$ carbon and $444 \mathrm{~kg}$ nitrogen (Fig. 10). Total sedimentation at the fish farm and along the transect was underestimated by 37 to $40 \%$ relative to the accumulation and effluxes of carbon and nitrogen at the seabed. This demonstrates that care should be taken in extrapolating trap data from point sources to a larger area in heterogeneous environments.

Earlier studies of salmon and trout farms have found environmental carbon loss of 78 to $84 \%$ (Gowen \& Bradbury 1987, Hall et al. 1990, Ackefors \& Enell 1994, Blackburn et al. 1996) and nitrogen loss of 72 to $81 \%$ (Gowen \& Bradbury 1987, Hall et al. 1992, Islam 2005); both are higher than the $67 \%$ carbon and $68 \%$ nitrogen loss in the present study. The difference is most likely a result of improved farming and feeding management during the last 2 decades, resulting in reduction of environmental impact per unit cultured fish (Brooks \& Mahnken 2003).

While carbon input to the farm in the form of feed is accounted for in fish biomass (33\%), in sedimentation $(6 \%)$ and through respiration (from 52 to $70 \%$ ), only $37 \%$ of nitrogen is accounted for by fish biomass and sedimentation (Fig. 10). Some nitrogen might have escaped the sediment as DON or through denitrification. This loss can be estimated (assuming the C:N ratio of trap material to be representative of particulate matter settling on the seabed), and this estimate may be multiplied by the sediment-derived accumulation of $\mathrm{OC}$, thereby deriving the total sedimentation of nitrogen. Surprisingly this value aligns well with the sum of the benthic inventory and net exchange of nitrogen (leaving only $6 \mathrm{~kg}$ of nitrogen unaccounted for across the benthic footprint) - despite the fact that measurements directly below the farm indicated that DON and $\mathrm{N}_{2}$ effluxes might be substantial. In sediments with conditions similar to those of the present study, i.e. high organic load, large ammonium efflux from the sediment, nitrate uptake, and presence of Beggiatoa spp., the $\mathrm{N}_{2}$ efflux amounts to 2 to $6 \%$ of DIN efflux
(Christensen et al. 2000, 2003, Bissett et al. 2009), which agrees well with the small amount of 'missing' nitrogen in the present study.

The C:N ratio of DIC and DIN effluents from the sediment decreased considerably within a short distance from the farm (Fig. 9f). Below the farm it was $30 \pm 17$, decreasing exponentially $\left(r^{2}=0.987\right)$ to $7 \pm 3$ at a distance of $60 \mathrm{~m}$ in the first transect. Thus the relative area of highly impacted sediment directly below the farm in relation to total footprint area implies that in total, the DIN flux approximates total mineralization quite well. However, since the carbon budget is balanced while a large proportion of the nitrogen is unaccounted for, most of this nitrogen was probably lost directly to the water column in an inorganic form.

Most carbon input with feed ended up as inorganic carbon due to fish respiration, while only $6.1 \%$ of the carbon input fell to the seabed (Fig. 10). The fraction of OC input settling to the seabed was less than measured or predicted in most other studies, where values have ranged between 29 and $71 \%$ (Gowen \& Bradbury 1987, Hall et al. 1990, Bergheim \& Asgard 1996). The fraction is even lower than the calculated fraction of $8.8 \%$, which assumed that $5 \%$ of the food input settles directly to the seabed (Brooks \& Mahnken 2003). This suggests a small food loss at the farm, which is also supported by the high $\mathrm{C}: \mathrm{N}$ ratio of settling particles. In other studies, the fraction of nitrogen input settling to the seabed is 11 to $28 \%$ (Gowen \& Bradbury 1987, Hall et al. 1992, Bergheim \& Asgard 1996), likewise higher than the $5 \%$ in the present study; however, we did not account for any DON or nitrogen efflux from the sediment. In addition we found higher remineralization efficiency than in comparable studies. In the present study, microbial processes in the sediment removed $56 \%$ of OC and $38 \%$ of nitrogen input to the sediment, while other studies found that microbial processes removed only from 3 to $25 \%$ of the OC input, and from 11 to $16 \%$ of the nitrogen input (Hall et al. 1990, 1992, Holmer et al. 2002, Carlsson et al. 2010). However, in those studies the input was measured by sedimentation traps moored close to the seabed, a factor which may have led to measurement of resuspended particles. Our mineralization efficiency is comparable to the controlled laboratory study by Valdemarsen et al. (2010), who found that 34 to $56 \%$ of OC added in the form of fish feed was released from the sediment as DIC and that 40 to $46 \%$ of nitrogen from fish feed was released as ammonium.

Assuming that the mass balance is valid for all the farmed fish in the fjord, the DIN released from these fish during the season with sufficient light for primary production (from April to September 2006 and from April to May 2007) amounted to $98700 \mathrm{~kg}$. At the same time, the DIN input into the euphotic layer from other 
sources (upwelling and runoff from land) is estimated to be $\sim 606000 \mathrm{~kg}$ (Gaard et al. 2011). Thus DIN release from farming activity represented $\sim 14 \%$ of total DIN input into the euphotic layer. Estimating the impact from the nutrient release by farmed fish on primary production is subject to large uncertainties, since a variable fraction of DIN input into the euphotic layer is exported without being incorporated into phytoplankton within the fjord (Gaard et al. 2011). Assuming that all available DIN was assimilated according to the Redfield ratio would give a new primary production figure (Dugdale \& Goering 1967) of $740 \mathrm{gC} \mathrm{m}^{-2}$. However, Gaard et al. (2011) found the new primary production to be $\sim 250 \mathrm{gC} \mathrm{m}^{-2}$. Thus, on average, approximately one-third of the DIN input into the euphotic layer was assimilated, while the remaining two-thirds was exported during the productive seasons. Due to variable nutrient concentrations in the euphotic layer, however, and to variable nutrient export rates, the influence on primary production is highly variable with time. When vertical mixing is high, additional DIN input (e.g. from fish farming) is expected to have minor influence on local primary production, and most of the nutrients are exported with the upper layer outflow. However, during extended calm periods, when nutrients in the upper layer often are depleted (Fig. 4c), most of the DIN release from farmed fish is probably assimilated within the fjord. Under these circumstances, the relative assimilation of anthropogenic nutrients is expected to be substantially higher than the long-time average of one-third of the DIN input, and this could potentially increase primary production substantially.

\section{Recovery}

During the $39 \mathrm{~d}$ pause in farming at this site (October to November 2006) substantial improvements in sediment conditions were observed (Figs. 6 \& 7).

The OC content in the top $6 \mathrm{~cm}$ of the sediment decreased significantly during the recovery period (Fig. 6), from 83.3 to $65.4 \mathrm{~mol} \mathrm{~m}^{-2}$. During the same period the sedimentation of POC was $0.8 \mathrm{~mol} \mathrm{~m}^{-2}$, and thus the total removal of OC during the $39 \mathrm{~d}$ can be estimated as $18.7 \mathrm{~mol} \mathrm{~m}^{-2}$, amounting to $22.4 \%$ of OC content at the beginning of the recovery period. It is generally anticipated that benthic mineralization rates decrease exponentially after a pulse-like carbon enrichment (Kelly \& Nixon 1984, Hansen \& Blackburn 1991, 1992, van Duyl et al. 1992, Kristensen \& Holmer 2001). At the farming site the benthic DIC release rate prior to the recovery period was $290 \mathrm{mmol} \mathrm{m}^{-2} \mathrm{~d}^{-1}$, a value that declined to $22 \mathrm{mmol} \mathrm{m}^{-2} \mathrm{~d}^{-1}$ after $39 \mathrm{~d}$. Assuming that the carbon mineralization rate de- creased exponentially during the period, and accounting for the DOC efflux, the total benthic mineralization equaled $6.1 \mathrm{~mol} \mathrm{~m}^{-2}$, corresponding to only $33 \%$ of $\mathrm{OC}$ removal as calculated from the sediment OC inventory above. Assuming a linear rather than an exponential decline in mineralization activity, the corresponding value for OC removal is $50 \%$. Thus both assumptions suggest the involvement of other processes in carbon removal during the recovery period. Potentially, methane release from the sediment could account for some of the 'missing' carbon, but more likely local resuspension of surface sediment caused by currents (and possibly by wild fish) played a bigger role. Resuspension would spread the carbon enrichment to the entire footprint area, and carbon mineralization and benthic solute exchange during resuspension events would be markedly enhanced. The latter aspect is not accounted for in our assessment of the benthic activity via standard core incubations. Indeed near-bottom trap data indicate some small degree of resuspension at all times, with resuspension actually increasing during the recovery period. At this time $51 \pm 3.4 \%$ and $63 \pm 3.5 \%$ of the flux at 40 and $45 \mathrm{~m}$ depth, respectively, was due to resuspended material (data not shown). Indications of resuspension may also be observed in the depth distribution of OC in the sediment (Fig. 6b), showing that the settling farming material with high OC content $(27 \pm 2.8 \%$ of dry wt) is not merely deposited at the sediment surface, but that it is mixed deeper into the sediment with otherwise lower OC content. Since macrofauna was absent or scarce, this intense downward mixing can be attributed to relocation of sediment due to resuspension. It is likely that local resuspension was a major factor for the observed fast recovery below the farm.

Acknowledgements. We thank the fish farming company P/F Tyggjará, for providing a boat and assistance in the field, as well as for information on their farming practices. We thank A. Glud for constructing microelectrodes, and S. Jacobsen for her assistance in the laboratory. This research was funded by grants from Statiol Faroes A/S, Chevron Føroyar ApS, Geysir Petroleum, the Faroese Research Council and the Aquaculture Research Station of the Faroes, the National Environmental Research Council (NE/F018612/1 and NE/ F0122991/1) and the commission for Scientific Research in Greenland (GCRC6507).

\section{LITERATURE CITED}

Ackefors H, Enell M (1994) The release of nutrients and organic matter from aquaculture systems in Nordic countries. J Appl Ichthyol 10:225-241

Archer D, Devol A (1992) Benthic oxygen fluxes on the Washington shelf and slope: a comparision of in situ microelectrode and chamber flux measurements. Limnol Oceanogr 37:614-629

Bergheim A, Åsgård T (1996) Waste production from aqua- 
culture. In: Baird DJ, Beveridge MCM, Kelly LA, Muir JF (eds) Aquaculture and water resource management. Blackwell Science, Oxford, p 50-80

Bissett A, Cook PLM, Macleod C, Bowman JP, Burke C (2009) Effects of organic perturbation on marine sediment betaproteobacterial ammonia oxidizers and on benthic nitrogen biogeochemistry. Mar Ecol Prog Ser 392:17-32

Black KD, Kiemer MCB, Ezzi IA (1996) The relationships between hydrodynamics, the concentration of hydrogen sulphide produced by polluted sediments and fish health at several marine cage farms in Scotland and Ireland. J Appl Ichthyol 12:15-20

Blackburn TH, Blackburn ND (1993) Rates of microbial processes in sediments (and discussion). Philos Trans R Soc Lond A 344:49-58

Blackburn TH, Hall POJ, Hulth S, Landén A (1996) Organic$\mathrm{N}$ loss by efflux and burial associated with a low efflux of inorganic $\mathrm{N}$ and with nitrate assimilation in Arctic sediments (Svalbard, Norway). Mar Ecol Prog Ser 141: 283-293

> Bower CE, Holm-Hansen T (1980) A salicylate-hypochlorite method for determining ammonia in seawater. Can J Fish Aquat Sci 37:794-798

Brooks KM, Mahnken CVW (2003) Interactions of Atlantic salmon in the Pacific northwest environment II. Organic wastes. Fish Res 62:255-293

Carlsson MS, Glud RN, Petersen JK (2010) Degradation of mussel (Mytilus edulis) fecal pellets released from hanging long-lines upon sinking and after settling at the sediment. Can J Fish Aquat Sci 67:1376-1387

Chamberlain J, Stucchi D (2007) Simulating the effects of parameter uncertainty on waste model predictions of marine finfish aquaculture. J Aquacult 272:296-311

Chen YS, Beveridge MCM, Telfer TC, Roy WJ (1999) Settling rate characteristics and nutrient content of the faeces of Atlantic salmon, Salmo salar L., and the implications for modelling of solid waste dispersion. Aquacult Res 30: 395-398

> Christensen PB, Rysgaard S, Sloth NP, Dalsgaard T, Schwærter S (2000) Sediment mineralization, nutrient fluxes, denitrification and dissimilatory nitrate reduction to ammonium in an estuarine fjord with sea cage trout farms. Aquat Microb Ecol 21:73-84

Christensen PB, Glud RN, Dalsgaard T, Gillespie P (2003) Impacts of longline mussel farming on oxygen and nitrogen dynamics and biological communities of coastal sediments. Aquaculture 218:567-588

> Cooke SJ, Chandroo KP, Beddow TA, Moccia RD, Mckinley RS (2000) Swimming activity and energetic expenditure of captive rainbow trout Oncorhynchus mykiss (Walbaum) estimated by electromyogram telemetry. Aquacult Res 31:495-505

Cromey CJ, Nickell TD, Black KD (2002) DEPOMOD: modelling the deposition and biological effects of waste solids from marine cage farms. Aquaculture 214:211-239

Dugdale RC, Goering JJ (1967) Uptake of new and regenerated forms of nitrogen in primary productivity. Limnol Oceanogr 12:196-206

FAO (Food and Agricultural Organization of the United Nations) (2009) The state of world fisheries and aquaculture 2008. FAO Fisheries and Aquaculture Department, Rome. Available at www.fao.org/docrep/011/i0250e/ i0250e00.htm

Fenchel T, King GM, Blackburn TH (2000) Bacterial biogeochemistry: the ecophysiology of mineral cycling, 2nd edn. Academic Press, London

Fernandez-Jover D, Sanchez-Jerez P, Bayle-Sempere J, Car- ratala A, Leon VM (2007) Addition of dissolved nitrogen and dissolved organic carbon from wild fish faeces and food around Mediterranean fish farms: implications for waste-dispersal models. J Exp Mar Biol Ecol 340:160-168

> Findlay RH, Watling L (1997) Prediction of benthic impact for salmon net-pens based on the balance of benthic oxygen supply and demand. Mar Ecol Prog Ser 155:147-157

Forsberg OI (1997) The impact on varying feeding regimes on oxygen consumption and excretion of carbon dioxide and nitrogen in post-smolt Atlantic salmon Salmo salar L. Aquacult Res 28:29-41

Gaard E, á Norði G, Simonsen K (2011) Environmental effects on phytoplankton production in a Northeast Atlantic fjord, Faroe Islands. J Plankton Res 33:947-959

Gardner WS, McCarthy MJ (2009) Nitrogen dynamics at the sediment-water interface in shallow, sub-tropical Florida Bay: why denitrification efficiency may decrease with increased eutrophication. Biogeochem 95:185-198

Giles H (2008) Using Bayesian networks to examine consistent trends in fish farm benthic impact studies. Aquaculture 274:181-195

Glud RN (2008) Oxygen dynamics of marine sediments. Mar Biol Res 4:243-289

Glud RN, Gundersen JK, Revsbech NP, Jørgensen BB, Huttel $M$ (1995a) Calibration and performance of the stirred flux chamber from the benthic lander Elinor. Deep-Sea Res I 42:1029-1042

Glud RN, Jensen K, Revsbech NP (1995b) Diffusivity in surficial sediments and benthic mats determined by use of a combined $\mathrm{N}_{2} \mathrm{O}-\mathrm{O}_{2}$ microsensor. Geochim Cosmochim Acta 59:231-237

Glud RN, Gundersen JK, Ramsing NB (2000) Electrochemical and optical oxygen microsensors for in situ measurements. In: Buffle J, Horvai G (eds) In situ monitoring of aquatic systems: chemical analysis and speciation. John Wiley \& Sons, Chichester, p 19-73

Glud RN, Gundersen JK, Røy H, Jørgensen BB (2003) Seasonal dynamics of benthic $\mathrm{O}_{2}$ uptake in a semienclosed bay: importance of diffusion and faunal activity. Limnol Oceanogr 48:1265-1276

Gowen RJ, Bradbury NB (1987) The ecological impact of salmonid farming in coastal waters: a review. Oceanogr Mar Biol Annu Rev 25:563-575

Grasshoff K, Kremling K, Erhardt M (1999) Methods for seawater analysis, 3rd edn (revised). Wiley, Weinheim

Grøttum JA, Sigholt T (1998) A model for oxygen consumption of Atlantic salmon (Salmo salar) based on measurements of individual fish in a tunnel respirometer. Aquacult Eng 17:241-251

Gundersen K, Wassmann P (1990) Use of chloroform in sediment traps: caution advised. Mar Ecol Prog Ser 64: $187-195$

Gundersen JK, Ramsing NB, Glud RN (1998) Predicting the signal of $\mathrm{O}_{2}$ microsensors from physical dimensions, temperature, salinity, and $\mathrm{O}_{2}$ concentration. Limnol Oceanogr 43:1932-1937

Hall POJ, Anderson LG, Holby O, Kollberg S, Samuelsson MO (1990) Chemical fluxes and mass balances in a marine fish cage farm. I. Carbon. Mar Ecol Prog Ser 61:61-73

Hall POJ, Holby O, Kollberg S, Samuelsson MO (1992) Chemical fluxes and mass balances in a marine fish cage farm. IV. Nitrogen. Mar Ecol Prog Ser 89:81-91

Hansen B (1990) Rák og útskifting í ovaru løgunum á føroyskum gáttarfirðum. Fiskirannsóknir 6:99-121

Hansen LS, Blackburn TH (1991) Aerobic and anaerobic mineralization of organic material in marine sediment microcosms. Mar Ecol Prog Ser 75:283-291 
Hansen LS, Blackburn TH (1992) Effect of algal bloom deposition on sediment respiration and fluxes. Mar Biol 112: $147-152$

Hargrave BT, Holmer M, Newcombe CP (2008) Towards a classification of organic enrichment in marine sediments based on biogeochemical indicators. Mar Pollut Bull 56: 810-824

Holmer M, Kristensen E (1992) Impact of marine fish cage farming on metabolism and sulfate reduction of underlying sediments. Mar Ecol Prog Ser 80:191-201

- Holmer M, Marbá N, Terrados J, Duarte CM, Fortes MD (2002) Impacts of milkfish (Chanos chanos) aquaculture on carbon and nutrient fluxes in the Bolinao area, Philippines. Mar Pollut Bull 44:685-696

Holmer M, Duarte CM, Heilskov A, Olesen B, Terrados J (2003) Biogeochemical conditions in sediments enriched by organic matter from net-pen fish farms in the Bolinao area, Philippines. Mar Pollut Bull 46:1470-1479

- Holmer M, Marba N, Diaz-Almela E, Duarte CM, Tsapakis M, Danovaro R (2007) Sedimentation of organic matter from fish farms in oligotrophic Mediterranean assessed through bulk and stable isotope $\left(\delta^{13} \mathrm{C}\right.$ and $\left.\delta^{15} \mathrm{~N}\right)$ analyses. Aquaculture 262:268-280

Hulth S, Tengberg A, Landén A, Hall POJ (1997) Mineralization and burial of organic carbon in sediments of the southern Weddell Sea (Antarctica). Deep-Sea Res I 44: 955-981

Islam MS (2005) Nitrogen and phosphorus budget in coastal and marine cage aquaculture and impacts of effluent loading on ecosystem: review and analysis towards model development. Mar Pollut Bull 50:48-61

Jeffrey SW, Humphrey GF (1975) New spectrophotometric equations for determining chlorophylls $a, b, c_{1}$ and $c_{2}$ in higher plants, algae and natural phytoplankton. Biochem Physiol Pflanz 167:191-194

Johansson D, Juell JE, Oppedal F, Stiansen JE, Ruohonen K (2007) The influence of the pycnocline and cage resistance on current flow, oxygen flux and swimming behaviour of Atlantic salmon (Salmo salar L.) in production cages. Aquaculture 265:271-287

Jørgensen BB (1982) Ecology of the bacteria of the sulphur cycle with special reference to anoxic-oxic interface environments (and discussion). Philos Trans R Soc Lond B Biol Sci 298:543-561

Jørgensen BB, Revsbech NP (1983) Colorless sulfur bacteria, Beggiatoa spp. and Thiovulum spp., in $\mathrm{O}_{2}$ and $\mathrm{H}_{2} \mathrm{~S}$ microgradients. Appl Environ Microbiol 45:1261-1270

Jørgensen BB, Revsbech NP (1985) Diffusive boundary layers and the oxygen uptake of sediments and detritus. Limnol Oceanogr 30:111-122

Juell JE (1995) The behaviour of Atlantic salmon in relation to efficient cage-rearing. Rev Fish Biol Fish 5:320-335

Kanneworf E, Nicolaisen W (1973) The 'HAPS': a frame supported bottom corer. Ophelia 10:119-129

Karakassis I, Pitta P, Krom MD (2005) Contribution of fish farming to the nutrient loading of the Mediterranean. Sci Mar 69:313-321

Kelly JR, Nixon SW (1984) Experimental studies of the effect of organic deposition on the metabolism of a coastal marine bottom community. Mar Ecol Prog Ser 17:157-169

Kempf M, Merceron M, Cadour G, Jeanneret H, Mèar Y, Miramand P (2002) Environmental impact of a salmonid farm on a well flushed marine site: II. Biosedimentology. J Appl Ichthyol 18:51-60

Kristensen E, Holmer M (2001) Decomposition of plant materials in marine sediment exposed to different electron acceptors $\left(\mathrm{O}_{2}, \mathrm{NO}_{3}^{-}\right.$, and $\left.\mathrm{SO}_{4}{ }^{2-}\right)$, with emphasis on sub- strate origin, degradation kinetics, and the role of bioturbation. Geochim Cosmochim Acta 65:419-433

Kutti T, Ervik A, Hansen PK (2007) Effects of organic effluents from a salmon farm on a fjord system. I. Vertical export and dispersal processes. Aquaculture 262:367-381

Lundsgaard C, Olesen M, Reigstad M, Olli K (1999) Sources of settling material: aggregation and zooplankton mediated fluxes in the Gulf of Riga. J Mar Syst 23:197-210

> McHatton SC, Barry JP, Jannasch HW, Nelson DC (1996) High nitrate concentrations in vacuolate, autotrophic marine Beggiatoa spp. Appl Environ Microbiol 62: 954-958

> Mente E, Pierce GJ, Santos MB, Neofitou C (2006) Effect of feed and feeding in the culture of salmonids on the marine aquatic environment: a synthesis for European aquaculture. Aquacult Int 14:499-522

Merceron M, Kempf M, Bentley D, Gaffet JD, Le Grant J, Lamort-Datin L (2002) Environmental impact of a salmonid farm on a well flushed marine site: I. Current and water quality. J Appl Ichthyol 18:40-50

Mortensen K (1990) Keldur til nitrogen, fosfor og lívrunnin evni í Skálafirði, Sundalagnum norðanfyri Streymin og Kaldbaksfirði. Fiskirannsóknir 6:287-309

Nickell LA, Black KD, Hughes DJ, Overnell J and others (2003) Bioturbation, sediment fluxes and benthic community structure around a salmon cage farm in Loch Creran, Scotland. J Exp Mar Biol Ecol 285-286:221-233

Nishio T, Koike I, Hattori A (1983) Estimates of denitrification and nitrification in coastal and estuarine sediments. Appl Environ Microbiol 45:444-450

Parsons TR, Maita Y, Lalli CM (1984) A manual of chemical and biological methods for seawater analysis. Pergamon Press, Oxford

Patursson Ø, Swift MR, Tsukrov I, Simonsen K, Baldwin K, Fredriksson DW, Celikkol B (2010) Development of a porous media model with application to flow through and around a net panel. Ocean Eng 37:314-324

Pillay TVR (2004) Aquaculture and the environment, 2nd edn. Blackwell Publishing, Oxford.

Pitta P, Apostolaki ET, Tsagaraki T, Tsapakis M, Karakassis I (2006) Fish farming effects on chemical and microbial variables of the water column: a spatio-temporal study along the Mediterranean Sea. Hydrobiologia 563:99-108

Pitta P, Tsapakis M, Apostolaki ET, Tsagaraki T, Holmer M, Karakassis I (2009) 'Ghost nutrients' from fish farms are transferred up the food web by phytoplankton grazers. Mar Ecol Prog Ser 374:1-6

Rasmussen H, Jørgensen BB (1992) Microelectrode studies of seasonal oxygen uptake in a coastal sediment: role of molecular diffusion. Mar Ecol Prog Ser 81:289-303

Revsbech NP (1989) An oxygen microsensor with a guard cathode. Limnol Oceanogr 34:474-478

Revsbech NP, Jørgensen BB (1986) Microelectrodes: their use in microbial ecology. In: Marshall KC (ed) Advances in microbial ecology. Plenum Publishing, New York, NY, p 293-352

Sakshaug E, Kristiansen S, Syvertsen E (1992) Planktonalger. In: Sakshaug E, Bjørge A, Gulliksen B, Loeng $H$, Mehlum F (eds) Økosystem Barentshavet. Mensa-Trykk, Lillehammer, p 79-108

Sanderson JC, Cromey CJ, Dring MJ, Kelly MS (2008) Distribution of nutrients for seaweed cultivation around salmon cages at farm sites in north-west Scotland. Aquaculture 278:60-68

Skogen MD, Eknes M, Asplin LC, Sandvik AD (2009) Modelling the environmental effects of fish farming in a Norwegian fjord. Aquaculture 298:70-75 
Sloth NP, Blackburn H, Hansen LS, Risgaard-Petersen N, Lomstein BA (1995) Nitrogen cycling in sediments with different organic loading. Mar Ecol Prog Ser 116:163-170

Soto D, Aguilar-Manjarrez J, Hishamunda N (eds) (2008) Building an ecosystem approach to aquaculture. Food Agricult Org Fish Aquacult Proc no. 14, Palma de Mallorca, 7-11 May 2007. FAO, Rome

Steemann-Nielsen E (1952) The use of radioactive carbon $\left({ }^{14} \mathrm{C}\right)$ for measuring organic production in the sea. J Cons Int Explor Mer 16:117-140

Strain PM, Hargrave BT (2005) Salmon aquaculture, nutrient fluxes and ecosystem processes in southwestern New Brunswick. In: Hargrave BT (ed) Environmental effects of marine finfish aquaculture. Springer-Verlag, Berlin, p 29-57

Valdemarsen T, Kristensen E, Holmer M (2009) Metabolic threshold and sulfide-buffering in diffusion controlled marine sediments impacted by continuous organic enrich-

Editorial responsibility: Hans Heinrich Janssen, Oldendorf/Luhe, Germany ment. Biogeochem 95:335-353

Valdemarsen T, Kristensen E, Holmer M (2010) Sulfur, carbon, and nitrogen cycling in faunated marine sediments impacted by repeated organic enrichment. Mar Ecol Prog Ser 400:37-53

van Duyl FC, Bak RPM, Kop AJ, Nieuwland G, Berghuis EM, Kok A (1992) Mesocosm experiments: mimicking seasonal developments of microbial variables in North Sea sediments. Hydrobiologia 235-236:267-281

Viollier E, Rabouille C, Apitz SE, Breuer E and others (2003) Benthic biogeochemistry: state of the art technologies and guidelines for the future of in situ survey. J Exp Mar Biol Ecol 285-286:5-31

- Wild-Allen K, Herzfeld M, Thompson PA, Rosebrock U, Parslow J, Volkman JK (2010) Applied coastal biogeochemical modelling to quantify the environmental impact of fish farm nutrients and inform managers. J Mar Syst 81:134-147

Submitted: July 15, 2010; Accepted: February 16, 2011 Proofs received from author(s): May 18, 2011 